\title{
New insight into the 2011-2012 unrest and eruption of El Hierro Island (Canary Islands) based on integrated geophysical, geodetical and petrological data
}

\author{
Stavros Meletlidis ${ }^{1}$, Alessio Di Roberto $^{2,{ }^{\star}}$, Itahiza Domínguez Cerdeña ${ }^{1}$, \\ Massimo Pompilio $^{2}$, Laura García-Cañada ${ }^{3}$, Antonella Bertagnini ${ }^{2}$, Maria Angeles Benito-Saz ${ }^{3}$, \\ Paola Del Carlo², Sergio Sainz-Maza Aparicio ${ }^{3}$
}

${ }^{1}$ Centro Geofisico de Canarias, Instituto Geográfico Nacional, Santa Cruz de Tenerife, Spain

${ }^{2}$ Istituto Nazionale di Geofisica e Vulcanologia, Sezione di Pisa, Pisa, Italy

${ }^{3}$ Observatorio Geofisico Central, Instituto Geografico Nacional, Madrid, Spain

\author{
Article history \\ Received March 2, 2015; accepted September 25, 2015. \\ Subject classification: \\ Volcano seismology, Mineralogy and petrology, Geological and geophysical evidences of deep processes, Rock geochemistry, \\ Measurements and monitoring, El Hierro, Magma ascent, Volcano Monitoring.
}

\begin{abstract}
A shallow water eruption started on October 10, 2011, $\sim 2 \mathrm{~km}$ south off the coast of El Hierro (Canary Islands, Spain). The eruption lasted about five months and ended by early March 2012. Three months of unrest preceded this event with more than 10,000 localized earthquakes and up to $6 \mathrm{~cm}$ of vertical ground deformation. In the Canary Islands, this is the first eruption to be monitored by the network of Instituto Geográfico National (IGN) since the very beginning of the seismic unrest. This provided unprecedented time series that include geophysical (seismic and gravimetric), geodetic, geochemical and petrological data. In this work we discuss and interpret these data in order to describe the mechanisms of 2011-2012 El Hierro eruption, including ascent from magmatic source, a crustal storage, and the final intrusion in the South Rift before the eruption. Our research approach provides a multidisciplinary view of the dynamics of magma ascent and improves previous interpretations formulated during or shortly after the end of the eruption. According to our results, a major intrusion occurred beneath and around preexisting highdensity magmatic bodies, localized at depth below the central part of the island. After a failed attempt to reach the surface through a low fractured zone located below the central-northern part of the island, the ascending magma finally found its way nearby the El Hierro South Rift Zone and erupted off the coast of La Restinga village, $350 \mathrm{~m}$ below sea level. The eruption was fed by the ascent of an important volume of material from the upper mantle that was emplaced near the crust-mantle boundary and progressively tapped during the eruption.
\end{abstract}

\section{Introduction}

The shallow submarine eruption that took place between October 10, 2011, and March 5, 2012, off the coast of La Restinga village in the south of El Hierro puts an end to the non-eruptive period of the Canary Islands that had lasted over 40 years, since the 1971 eruption in La Palma Island.

The lack of information about the eruptive activity of El Hierro Island, and more generally on shallow water volcanic eruptions, led the scientific community to invest a great effort on the meticulous registration of geophysical and geodetical time series for this unprecedented eruption. This was possible thanks to the monitoring network of Instituto Geográfico National (IGN) that was present on the island before the onset of eruptive unrest and that was promptly enhanced during the crisis. Notwithstanding this prompt and large monitoring effort, uncertainties derived from incomplete scientific knowledge and limited data described for shallow water eruptions have resulted in difficulties for managing the eruptive crisis and a severe impact on the island's economy. Recently some models have been proposed to describe the dynamics of magma intrusion and ascent driving to the 2011-2012 eruption [see Martí et al. 2013a, Martí et al. 2013b, García et al. 2014, Longpré et al. 2014]. These models are based on the analysis of seismic data registered in the IGN seismic catalogue (www.ign.es), ground deformation detected by GPS network and on the petrological study of erupted products. With only minor differences between them, these researches propose that the eruption was driven by the ascent of a mantle-derived magma [Martí et al. 2013a, 
Martí et al. 2013b, Longpré et al. 2014] initially accumulated in a reservoir located at a depth of about 20-25 $\mathrm{km}$ below the El Hierro Island and possibly originated by the mixing and hybridization of two magmas from distinct mantle reservoirs [Longpré et al. 2014]. This magma would have ascended aseisimically and progressively accumulated in the lower crust (during about two months), reaching a level of stagnation at 10-15 $\mathrm{km}$. After a $\sim 15 \mathrm{~km}$-long subhorizontal migration toward the SE, the magma would have finally ascended to the eruption site, off the coast of La Restinga village [Martí et al. 2013a, Martí et al. 2013b, García et al. 2014, Longpré et al. 2014].

In this paper we combine the temporal analysis of seismic events, ground deformation patterns and gravity data with a detailed mineralogical and geochemical analysis of products systematically sampled during the eruption and with the thermodynamical modeling of magma differentiation. We use the hypocentral positions recently relocated by Domínguez Cerdeña et al. [2014]. This research approach allows to give a multidisciplinary view of the dynamics of magma ascent and improves previous interpretations formulated during or shortly after the end of the eruption. According to our model the eruption was fed by a single batch of

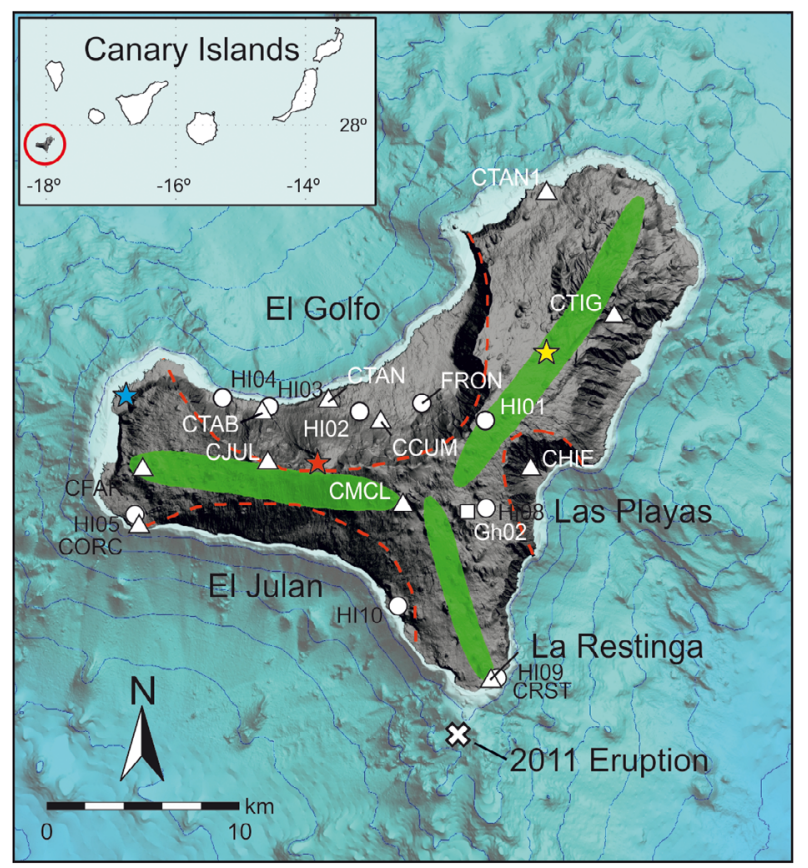

Figure 1. Map of El Hierro Island with highlighted the main morphological features. Green shaded zones: rift lines. Red dashed lines: Landslides scars. Stars indicate the most recent eruptions on the island; yellow star: Las Chamuscadas, red star: Tanganasoga and blue star: Lomo Negro. White cross: location of the vent of the 2011-2012 eruption. In map are also highlighted the position of instruments of multiparametric monitoring network that was deployed on the island by Instituto Geográfico Nacional: triangles - Seismic stations; circles permanent GPS stations; squares - permanent gravimetric station. mantle-derived magma progressively tapped at variable rates from October 2011 to March 2012. Magma feeding the eruption experienced a stepwise migration between three main magmatic environments, including a deep reservoir, a crustal magma reservoir and a final shallow conduit and vent zone.

\section{Geological background}

El Hierro, located at the south-western end of the Canary Islands (Figure 1), is the emergent summit $(\sim 1500 \mathrm{~m})$ of a much wider volcanic shield $\left(280 \mathrm{~km}^{2}\right)$, which rises from a water depth of $3800-4000 \mathrm{~m}$. It is the youngest island of the Canarian Archipelago, with the oldest subaerial rocks cropping out on the island that have been dated at 1.12 Ma [Guillou et al. 1996]. The subaerial part of El Hierro is formed by two main volcanic edifices, the Tiñor volcano on the north-east flank of the island, built approximately between $0.88-1.12 \mathrm{Ma}$ and El Golfo volcano in the north-west flank, built between 550-130 ka. Products belonging to Tiñor volcano

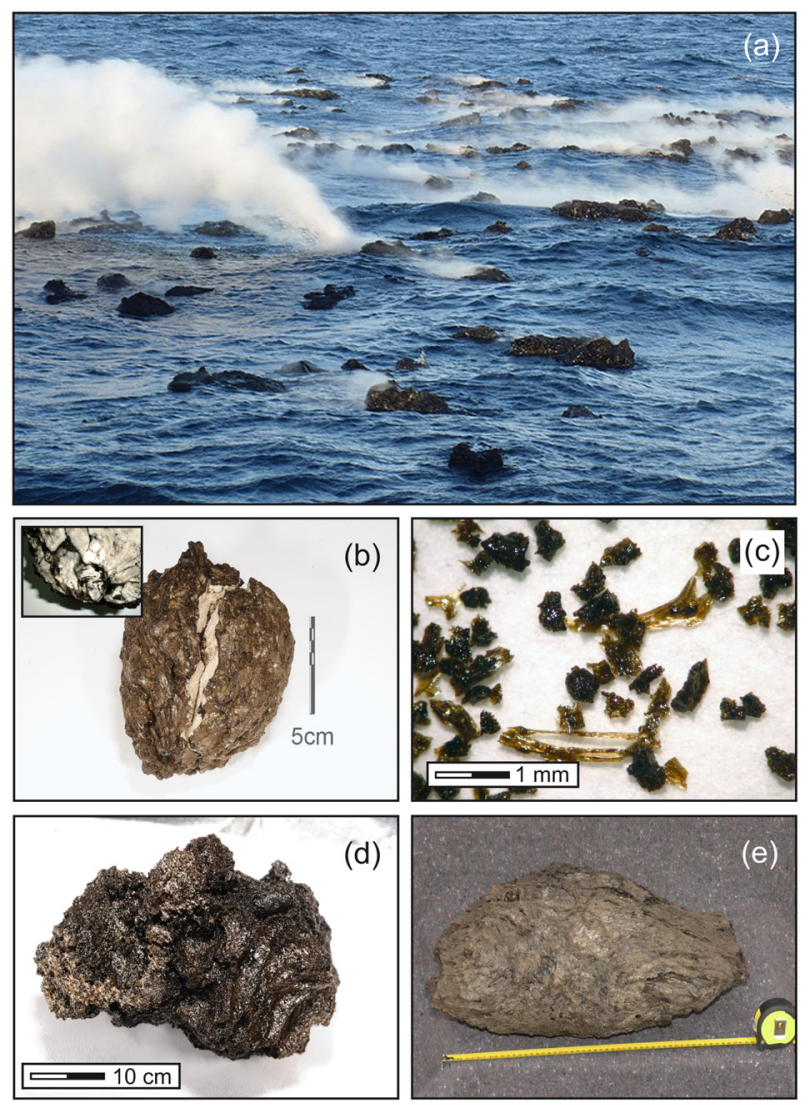

Figure 2. Images of volcanic products emitted during the 2011-2012 eruption. (a) Hot scoriaceous blocks and "lava balloons" floating on the sea surface during the eruption; (b) "coconut-like" bomb consisting of an outer basanite crust embedding a pumiceous xenolith [Troll et al. 2011, Meletlidis et al. 2012, Sigmarsson et al. 2012, Del Moro et al. 2015]; (c) example of the juvenile ash and fine lapilli sampled in water column on November 5, 2011, and February 12, 2012; (d) floating lava block erupted during the first days of the eruption; (e) elliptical-shaped "lava balloon". 
mainly consist of picritic to hawaiitic-tephritic massive lavas whereas El Golfo volcano is characterized by nephelinitic to trachytic composition [Carracedo et al. 2001]. These two main edifices are separated by the gravitational collapse of the Tiñor volcano occurred at ca. 0.88 Ma [Guillou et al. 1996, Carracedo et al. 2001, Münn and Klügel 2006]. The last eruptive stage, known as Quaternary rift volcanism, has been very active since $134 \mathrm{ka}$, and it is characterized by alkali picrites, basanites and tephrites that can be observed in exceptional detail all along the three rifts (NE-, W- and S-Ridge) of the island [Guillou et al. 1996, Acosta et al. 2003]. This volcanic activity has produced a large number of cones in the emerged part of El Hierro Island and an even greater number on its submarine flanks as shown by recent investigations [Rivera et al. 2013]

The most recent subaerial eruption, Volcán de Lomo Negro occurred in the western part of the island, outside of El Golfo landslide area (Figure 1), possibly between 115 BC and 1602 AD [Villasante-Marcos and Pavón-Carrasco 2014]. More recently, in 1793 AD a seismic crisis occurred at El Hierro and was likely related to an event of magma intrusion at depth or to a submarine eruption at the southern off-shore ridge of the island [Villasante-Marcos and Pavón-Carrasco 2014].

\section{The 2011-2012 unrest and eruption}

During the second fortnight of July 2011, the seismic stations of IGN started to register anomalous seismicity (up to 200 events per day) with hypocenters preliminarily located in the area of El Golfo and at depths of 8-12 km (IGN Seismic Bulletin). In the following two months, there was only a minor migration of the seismic hypocenters accompanied by ground deformation, diffuse emission of $\mathrm{CO}_{2}$, anomalous values of the magnetic field and $\mathrm{Rn}^{222}$ and $\mathrm{H}_{2} \mathrm{~S}$ efflux [Lopez et al. 2012, Pérez et al. 2012]. In the last days of September seismicity clearly migrated to the south and finally the eruption started on October 10, 2011, after at least 10,000 localized seismic events and a maximum vertical deformation of up to $6 \mathrm{~cm}$. The onset of the eruption was accompanied by harmonic volcanic tremor recorded by the seismic network of IGN in the western Canaries and 48 hours later by the appearance of a plume of stained and discolored water at $\sim 2 \mathrm{~km}$ south the coast of La Restinga village $\left(27^{\circ} 37.18\right.$ $17^{\circ} 59.58$; Figure 1) off the southern tip of the island. Repeated multibeam surveys revealed that the eruption occurred in a gully aligned in a NE-SW direction, almost perpendicular to the South Rift and at water depths between $\sim 363$ and $89 \mathrm{~m}$, with several vents that functioned simultaneously [Rivera et al. 2013]. Data document repeated cycles of collapse and subsequent
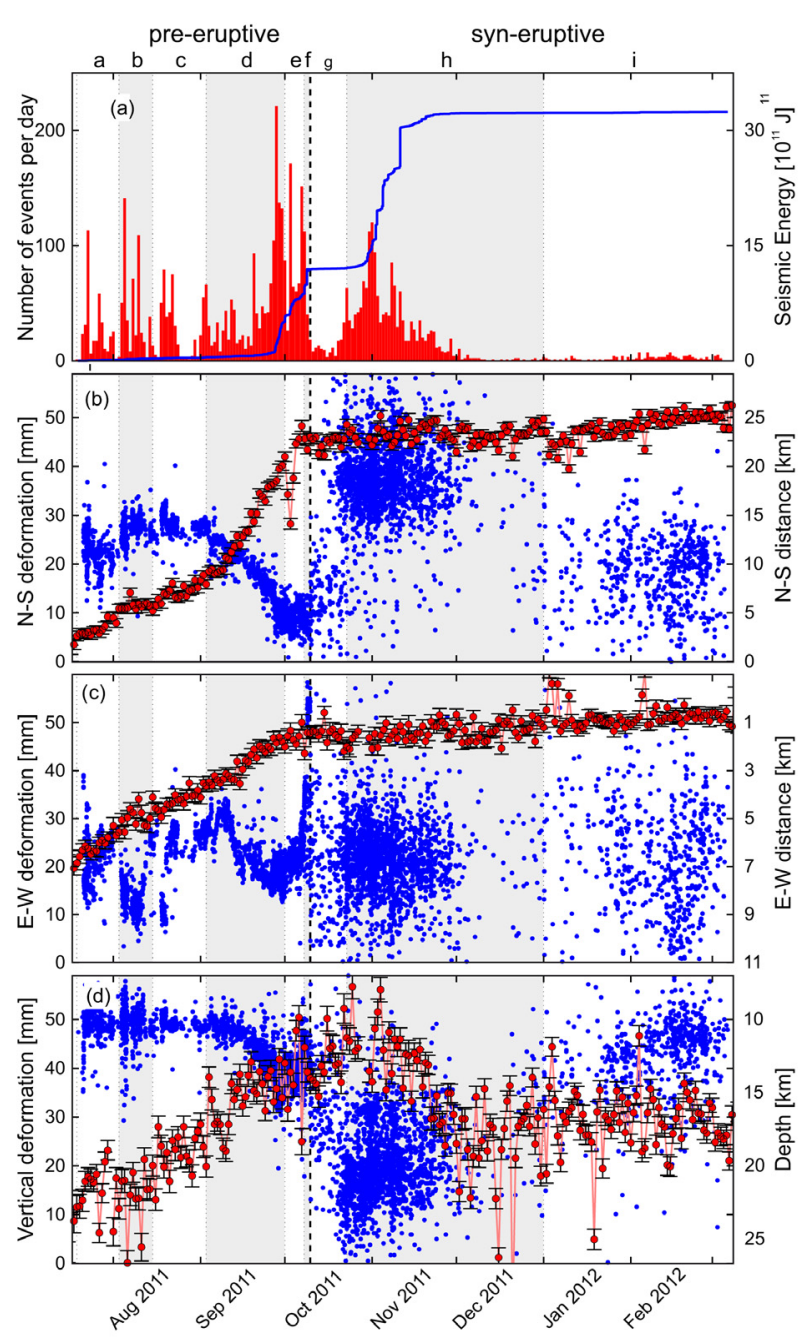

Figure 3. (a) Temporal evolution of the daily number of earthquakes with magnitude $>1.5$ (red histograms) and the accumulated seismic energy curve (blue line). (b-d) Blue dots: temporal evolution of the (b) North-South and (c) East-West distances ( $\mathrm{km}$ ) to the vent and of the $(\mathrm{d})$ depth $(\mathrm{km})$ of the earthquakes after relocation of Domínguez Cerdeña et al. [2014]; red dots (with the axis error) N-S, E-W and vertical components of ground deformation recorded at GPS station FRON (the only station that was active since the very onset of the unrest) during the pre-eruptive and syn-eruptive phases of the 2011-2012 El Hierro eruption. Black dashed line indicates the onset of the eruption. Shaded and white alternating areas indicate the nine phases in which authors divided the pre-eruptive unrest and eruptive activity.

regrowth of the cone with a total accumulated volume in the order of $329 \times 10^{6} \mathrm{NDRE} \mathrm{m}^{3}$ [Rivera et al. 2013]. The eruption produced a variety of volcanic material; some of the pyroclastic products were floating and therefore it was possible to sample them extensively on the sea surface during the entire duration of the eruption (Figure 2). First massive emission of volcanic materials occurred on October 15, 2011 even though small fragments $(<5 \mathrm{~cm})$ had been observed floating since October 12, 2011. Products included anomalous "coconut-like" bombs (Figure $2 \mathrm{~b}$ ), consisting of a vesicular crust with bulk basanite composition enveloping a pumiceous xenolith with trachytic to rhyolitic compo- 

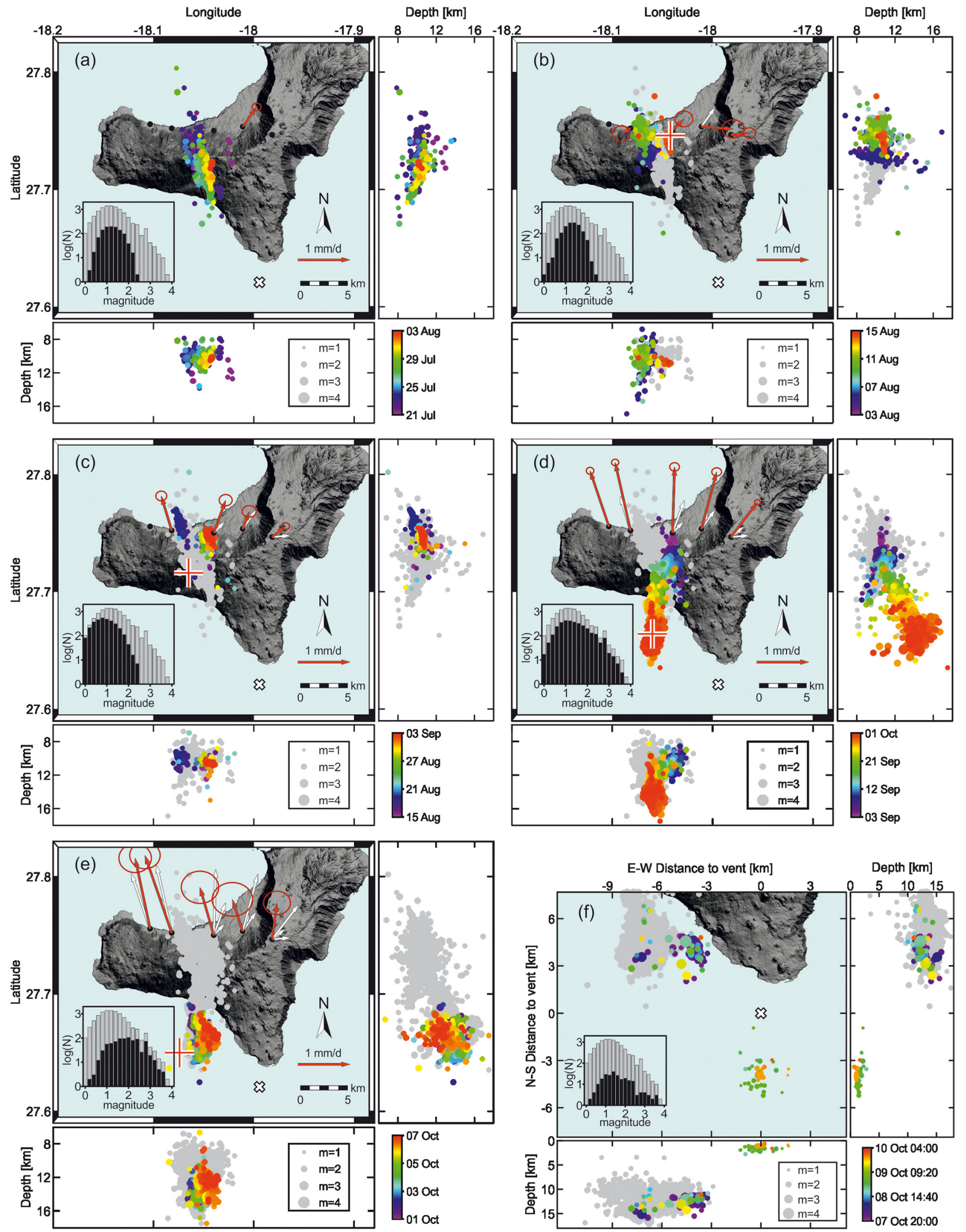

Figure 4. Temporal evolution of the latitude, longitude and depth $(\mathrm{km})$ of the earthquakes with magnitude $>1.5$ (time scale of events is reported in the color bar and in grey are reported the earthquakes occurred during the previous phases) along with the evolution of the horizontal deformation registered by GPS stations (red arrow for the period in analysis and white arrow for the previous periods) during the pre-eruptive phase of 2011-2012 eruption of El Hierro Island. In grey are reported the earthquakes occurred in the previous phases. Red cross indicates the position of the deformation source according to Mogi model and white X marks the vent of 2011-2012 eruption. Inner plots give the histograms of the number of located events versus magnitude for the each phase (black) and for the full period (grey shaded). Seismic data are after relocation of Domínguez Cerdeña et al. [2014]. 
sition [Troll et al. 2011, Meletlidis et al. 2012, Sigmarsson et al. 2012, Del Moro et al. 2015]. This type of products was emitted exclusively during the first days of the eruption and the main volume was produced on October 15,2011 . In late October and in the first days of November the eruption consisted of intense degassing episodes producing strong bubbling (up to $15 \mathrm{~m}$-high bubble emerged on the sea surface) accompanied with the emission of abundant ash and floating scoriaceous fragments (Figure 2c-d) [Santana-Casiano et al. 2013]. On November 27, and for the next three months, lava balloons were observed while floating and degassing on the sea surface (Figure 2a). These are unusual products consisting of an internal gas-filled cavity surrounded by a few centimeters-thick crust of quenched vesicular lava (Figure 2e). In El Hierro they range in size between 30 and $200 \mathrm{~cm}$. The emission of lava balloons continued until February 23, 2012. The eruption lasted for $\sim 5$ months and was officially declared ended on March 5 , 2012, with the top of the new submarine cone reaching the depth of $89 \mathrm{~m}$ b.s.l. [Rivera et al. 2013].

\section{Methods and materials}

Geophysical and geodetical signals acquisition methods and processing techniques as well as methods for the sampling and study of erupted products are reported in the Supplementary materials.

\section{Results}

\subsection{Time variation of geophysical signals}

The analysis of seismic activity, gravity changes and ground deformation allowed to distinguish six preeruptive and three syn-eruptive phases during the unrest and the following eruption (Figures 3-6).

\subsubsection{Pre-eruptive}

Phase A; July 21, 2011 - August 3, 2011 (Figure 4a). The first seismic swarm was recorded on July 21, 2011 and was characterized by low-energy earthquakes located at depth of 8-14 km beneath the south-central sector of the island. During this phase the seismic activity suffered a $\sim 3 \mathrm{~km}$, short-term horizontal migration at depths of $10-12 \mathrm{~km}$ and toward the north. This occurred through repeated, low-energy and intermittent swarms (Figure 3a). Since 7 July, 2011, and for the whole period, the only GPS station operating on the island (FRON) registered a ground deformation vector directed to the NE (red arrow in Figure 4a) [López et al. 2012].

Phase B; August 3, 2011 - August 15, 2011 (Figure 4b). Low-energy seismic activity registered in the previous phase continued with hypocenters located at 9-10 km. Earthquake swarms were again intermittent and separated by periods of relative repose (Figure 3a). GPS network registered a radial distribution of ground deformation; in fact, HI01, HIO2 and FRON stations, located in the central part of the island, recorded ground displacements towards E and NE whereas HI03 station, located in the western sector of the island, registered a movement towards $\mathrm{W}$.

Calculation of Mogi [1958] source parameters indicated that the deformation center (red/white cross) was located beneath the central part of the island at depth of $\sim 5 \mathrm{~km}$. The volume was estimated in the order of $10 \times 10^{6} \mathrm{~m}^{3}$ (Table 1 ).

Phase C; August 15, 2011 - September 3, 2011 (Figure $4 \mathrm{c})$. In this period the second highest b-value $(>2)$ [Gutenberg and Richter 1954] for the whole seismic unrest was achieved, as reported by Ibáñez et al. [2012] and Martí et al. [2013a, 2013b]. The earthquakes were clustered mainly at the margins of the area previously affected by the seismic activity and were located at depths shallower than $12 \mathrm{~km}$ (Figure 4c). The HI03 and HI02 GPS stations showed a strong increase in the ground deformation and a change in the vector direction towards NNW and NNE, respectively (Figure 4c). The source of deformation was determined to lay $\sim 5$ $\mathrm{km}$ beneath the center of the island and its volume was estimated in ca. $30 \times 10^{6} \mathrm{~m}^{3}$ (Table 1).

Phase D; September 3, 2011 - October 1, 2011 (Figure $4 d)$. In this period, the seismic events were initially located at depths of 10-12 km, on the eastern margin of the area previously affected by seismic activity. On late September, after a brief period of relatively low seismic activity, the number and magnitude of seismic events resumed, and hypocenter locations progressively migrated south and deepened at $12-16 \mathrm{~km}$. All the GPS stations recorded strong acceleration in the ground de-

\begin{tabular}{ccccc} 
Period & Longitude & Latitude & Depth $(\mathrm{km})$ & Volume $\left(\mathrm{m}^{3}\right)$ \\
\hline August 3, 2011 - August 15, 2011 & $-18,042$ & 27,746 & 4.9 & $10 * 106$ \\
\hline August 15, 2011 - September 3, 2011 & $-18,065$ & 27,716 & 4.9 & $30 * 106$ \\
\hline September 3, 2011 - October 1, 2011 & $-18,06$ & 27,664 & 3.8 & $160 * 106$ \\
\hline October 1, 2011 - October 7, 2011 & $-18,074$ & 27,65 & 5.0 & $50 * 106$ \\
\hline
\end{tabular}

Table 1. Position (latitude, longitude and depth) of deformation sources and volume calculated according to Mogi [1958] model. 
MELETLIDIS ET AL.

\begin{tabular}{|c|c|c|c|c|c|}
\hline $\begin{array}{l}\text { Month/day } \\
\text { of emission }\end{array}$ & October & November & December & January & February \\
\hline 1 & & $S$ & LB & LB & LB \\
\hline 2 & & $S$ & & & LB \\
\hline 3 & & $S$ & & LB & \\
\hline 4 & & $S$ & LB & $\mathrm{LB}^{*}$ & \\
\hline 5 & & $\mathrm{D} / \mathrm{Ash}^{*}$ & & & \\
\hline 6 & & D/Ash* & $\mathrm{LB}^{*}$ & LB & LB \\
\hline 7 & & & $\mathrm{LB}$ & $\mathrm{LB}$ & \\
\hline 8 & & $\mathrm{D}$ & & $\mathrm{LB}^{*}$ & LB \\
\hline \multicolumn{6}{|l|}{9} \\
\hline 10 & & & LB & & \\
\hline 11 & & & LB & & \\
\hline 12 & & & & & Ash* \\
\hline \multicolumn{6}{|l|}{13} \\
\hline 14 & & $\mathrm{LB}^{*}$ & $\mathrm{LB}$ & & \\
\hline 15 & Xen* & & & & \\
\hline 16 & & $\mathrm{LB}^{*}$ & & & \\
\hline \multicolumn{6}{|l|}{17} \\
\hline 18 & & & & $\mathrm{LB}^{*}$ & \\
\hline 19 & & LB & & $\mathrm{LB}^{*}$ & \\
\hline 20 & & & & LB & \\
\hline 21 & & & & LB* & \\
\hline 22 & & & & $\mathrm{LB}$ & \\
\hline 23 & & & & & LB \\
\hline \multicolumn{6}{|l|}{24} \\
\hline 25 & & & & $\mathrm{LB}$ & \\
\hline 26 & & LB & & LB & \\
\hline 27 & & $\mathrm{LB}^{*}$ & & $\mathrm{LB}^{*}$ & \\
\hline 28 & & & & LB* & \\
\hline 29 & $S$ & & & LB & \\
\hline 30 & & & LB & $\mathrm{LB}^{*}$ & \\
\hline 31 & $S^{*}$ & & LB & LB & \\
\hline
\end{tabular}

Table 2. Calendar with the days of emission and sampling of volcanic ash (in the water column), floating scoria and lava balloons. The days of intense degassing are included as well. Xen = xenopumice; Ash = volcanic ash in water column; $S=$ scoriaceous blocks; $\mathrm{D}=$ days with intense degassing; LB = lava balloons. Asterisks indicate days when sampling of products was possible.

formation with vectors showing a radial pattern (Figure $4 \mathrm{~d}$ ). The deformation center moved further toward the south, following the migration path of hypocenters and was determined to lay off the coast of El Julan depression at depth of $\sim 3.8 \mathrm{~km}$, approximately $1 \mathrm{~km}$ shallower than in the previous phase (Table 1). The volume was calculated in $160 \times 10^{6} \mathrm{~m}^{3}$, which is the highest estimated value for the entire eruption (Table 1).

Phase E; October 1, 2011 - October 7, 2011 (Figure 4e). Seismic events drastically increased in magnitude and clearly migrated in southeast direction and at depths of $10-11 \mathrm{~km}$. During this phase more than $50 \%$ of the total seismic energy of the unrest phase was released (Figure 3a). The direction of deformation vectors changed and almost all the stations registered vectors directed to- wards NNW. The deformation center was calculated to lay still offshore the coast of El Julan, at depth of $\sim 5 \mathrm{~km}$ and $\sim 1 \mathrm{~km}$ deeper than in the previous phase, with an estimated volume in the order of $50 \times 10^{6} \mathrm{~m}^{3}$ (Table 1).

From 22:24 UTC on October 7 to $\sim 05: 00$ UTC, on October 8 , a sequence of anomalies in the gravimeter sensors were registered including: a) an initial small increment in the gravity value of $3 \mu \mathrm{Gal}, \mathrm{b}$ ) a very strong movement of the ground lasting for at least $30 \mathrm{~min}-$ utes and followed by c) continuous tilting of the sensor (Figure 5).

Phase F; October 7, 2011 - October 10, 2011 (Figure $4 \mathrm{f})$. After $\sim 12$ hours of relative seismic silence, on October 8, 2011, at 20:34 UTC a seismic event with $\mathrm{ML}=4.3$ was recorded off the SW coast of the island at a depth 


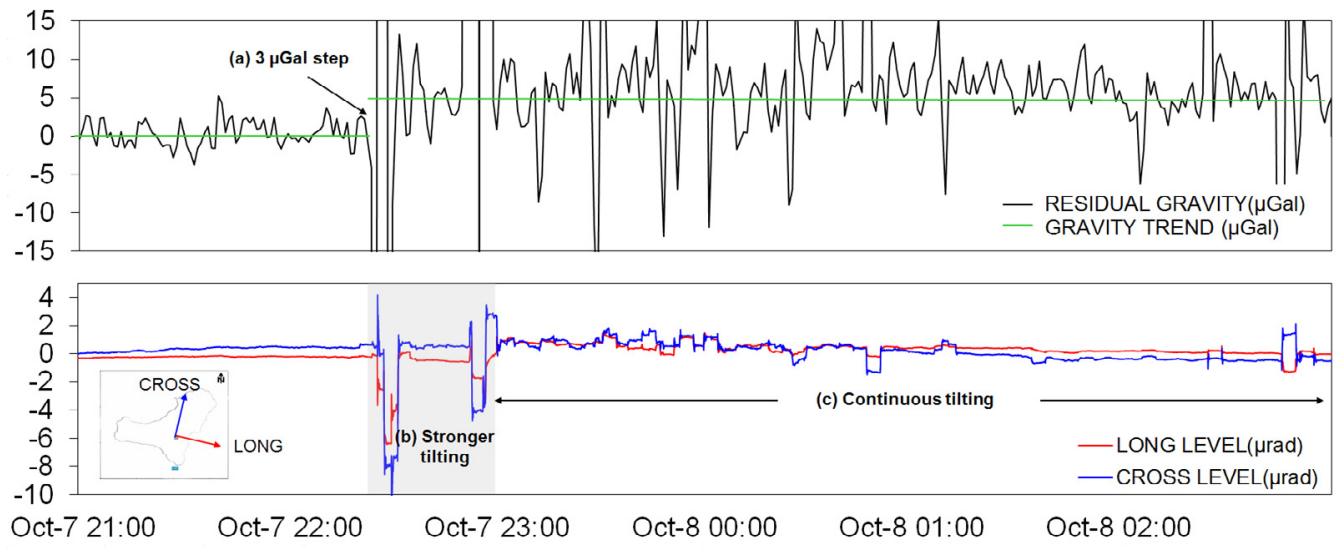

Figure 5. (a) Residual gravity record ( $\mu \mathrm{Gal}$ ) filtered at 1 minute and (b) long and cross level values ( $\mu$ rad) in the period between the night of October 7, and the early morning of October 8, 2011. The inset in the lower part of the plot shows, the cross and long directions of the two levels within the gravimeter.
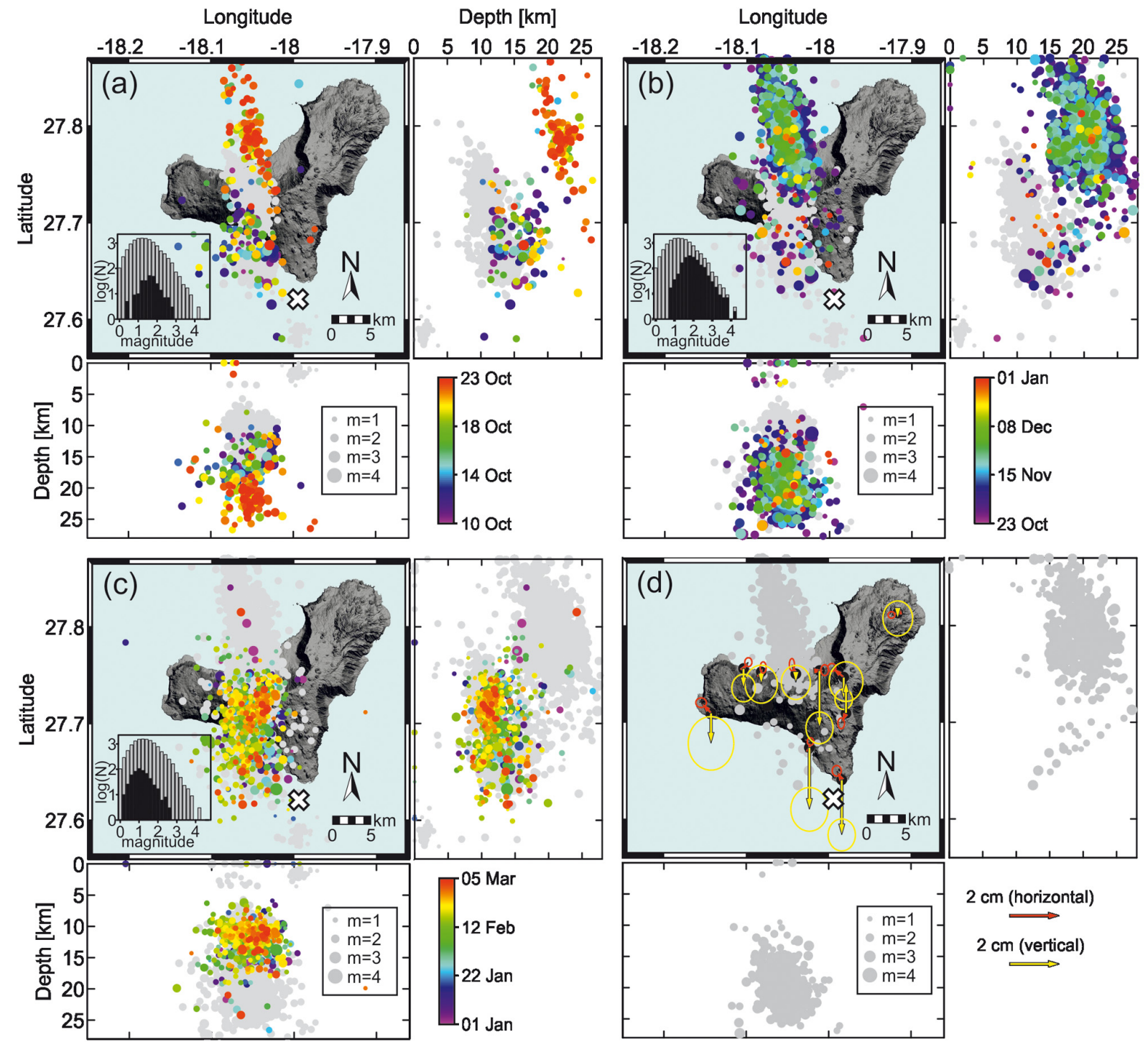

Figure 6. (a-c) Temporal evolution of the latitude, longitude and depth $(\mathrm{km})$ of the earthquakes with magnitude $>1.5$ (time scale of events is reported in the color bar and in grey are reported earthquakes occurred in the previous phases) during the syn-eruptive phase of $2011-2012$ eruption of El Hierro Island. White X marks the vent position for the 2011-2012 eruption. In grey are reported earthquakes occurred in the previous phases. Inner plots give the histograms of the number of located events versus magnitude for the each phase (black) and for the full period (grey shaded). Seismic data are after relocation of Domínguez Cerdeña et al. [2014]. (d) Red and yellow vectors show horizontal and vertical ground displacement respectively from November 6, 2011, to January 1, 2012 (within eruptive phase F) during which a minor episode of gradual ground deflation was registered by GPS network. Arrows are tipped with $75 \%$ confidence ellipses/circles and seismicity for the same period is plotted as grey circles. The white cross in all panels marks the position of vent for the 2011-2012 eruption. 
of $\sim 12 \mathrm{~km}$. This was the largest event registered since the beginning of the seismic unrest and marked the transition toward a new trend in the hypocentral characteristics of the following earthquakes. In fact after this event, the seismicity showed a sharp migration to the south, and reached a position located at a horizontal distance of $\sim 13 \mathrm{~km}$ from the previous position and at a depth shallower than $3 \mathrm{~km}$. During the first 26 hours of this phase the earthquakes were randomly spaced over an area of $18 \mathrm{~km}^{2}$ (green dots in Figure 4f) and later, they were characterized by a lower mean magnitude (mbLg) and were clustered at depth of $1 \mathrm{~km}$ in area of ca. $3 \mathrm{~km}^{2}$ (orange dots in Figure $4 \mathrm{f}$ ). Ground deformation, which had rapidly and continuously increased since the onset of the seismic unrest, suddenly slowed on October 8, 2011 (Figure 3a,b).

\subsubsection{Syn-eruptive activity}

Phase G; October 10, 2011 - October 23, 2011 (Figure $6 a)$. Since the beginning of the eruption and for about one week, seismic activity was localized mainly off the coast of El Julan, at depths of 10-14 km (Figure 6a). In this period seismicity was also registered at depth of 20$25 \mathrm{~km}$ off the El Golfo depression (Figure 6a).

Phase H; October 23, 2011 - January 1, 2012 (Figure $6 b)$. During the last week of October until early January, seismic activity was localized in the central-northern part of the island and had the highest magnitudes ever registered (except for the $\mathrm{ML}=4.3$ event of October 8,2011$)$. This seismicity developed at two different depths, with a first swarm at a ca. $20-25 \mathrm{~km}$ and the second one, which began a week later, at 15-20 km. Both swarms shared some common signal characteristics, consisting of an initial, persistent and progressive increase in the magnitude and number of seismic events culminating in relatively large events and followed by a drop in both the parameters [García et al. 2014]. Rare earthquakes occurred at depths of 10-14 km in the center-southern part of the island.

On early November a minor episode of gradual ground deflation was registered by GPS network (Figure 6d). This event lasted only four weeks and was registered especially in HI09 and HI10 stations located in the south of the island (Figure 6d) and FRON (in El Golfo) whereas most of the other stations showed no significant changes (above the background noise level) in the ground deformation vector until the end of the eruption.

Phase I; January 1, 2012 - March 5, 2012 (Figure 6c). In the final stage of the eruption, from early January to March, the seismic activity was again located in the central-southern part of the island with hypocenters at depth of 10-15 km. Except for negligible fluctuations, no significant deflation was observed in the horizontal and vertical components of ground deformation (Figure 3b,c).

\subsection{Textures, mineral phases and composition of erupted} products

All samples are porphyritic rocks. Products emitted during from 15 to 31 October, 2011, have a low phenocrysts content $<5$ vol. \%, whereas since early November phenocryst content gradually increased reaching values of ca. 20 vol. \%. Phenocrysts include clinopyroxene, olivine and spinel. Groundmass shows the same mineral assemblage. In floating scoriaceous fragments and lava balloons, the outer portion that was originally
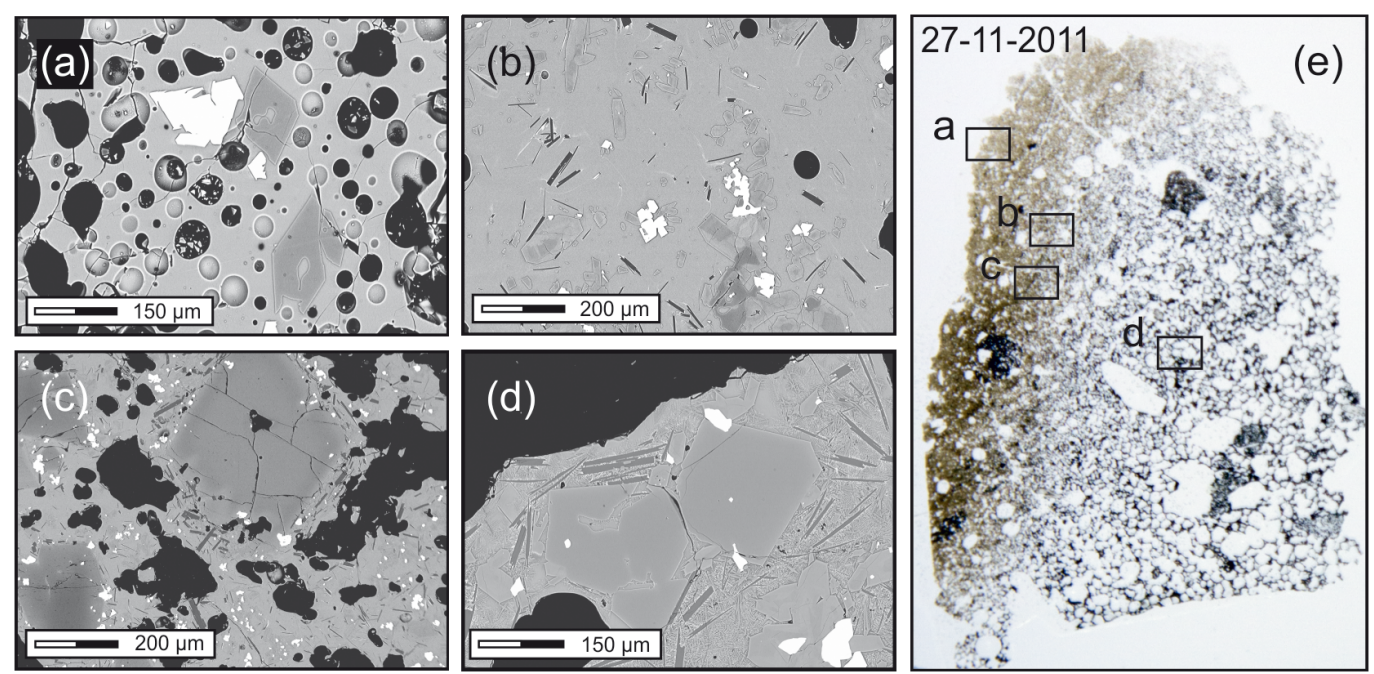

Figure 7. Scanning electron microscope (SEM) backscattered and optical microscope images representative of groundmass textures observed in floating scoriaceous fragments and of lava balloons. (a) External portion originally in contact with seawater showing a completely glassy groundmass. (b-c) intermediate portion of the external crust with abundant microphenocrysts of olivine, clinopyroxene, spinel and plagioclase and skeletal microlites mostly of clinopyroxene. (d) Groundmass with intersertal texture made of microlites of clinopyroxene, spinels and plagioclase. (e) Positions where a-d images have been acquired. 
in contact with seawater, is almost completely glassy and microlite-free (Figure 7a,e). This portion grades into a glassy groundmass with abundant microphenocrysts of olivine, clinopyroxene, spinel and plagioclase as large as 200-300 $\mu \mathrm{m}$, and skeletal microlites consisting mostly of clinopyroxene and minor spinels and plagioclase (Figure $7 \mathrm{~b}, \mathrm{c}, \mathrm{e})$. The abundance of skeletal microlites progressively increases as distance from the external crust increases. In the internal portion of samples, groundmass shows an intersertal texture (Figure 7d,e). All studied samples exhibit the zoned texture described above with the only exception of the scoriaceous and glassy crust $(<3 \mathrm{~cm})$ embedding the xenopumices erupted on October 15, 2011 and of ash samples recovered in the water column that are completely glassy.

Olivine occurs as isolated phenocrysts $(<1 \mathrm{~mm})$ and micro-phenocrysts $(<500 \mu \mathrm{m})$ and in glomeroporphyritic aggregates with interstitial clinopyroxene and spinel (Supplementary Figure 1). Morphology of the crystals is highly variable (Supplementary Figure 1) including embayed boundaries, skeletal or faceted shapes indicating rapid growth of the crystals.

As a whole, olivine phenocryst exhibit little variation in composition between cores and rims with more than $75 \%$ of measured composition peaked around $\mathrm{Fo}_{79-81}$. Larger olivine phenocrysts are usually normally zoned with $\mathrm{Mg}$-rich $\mathrm{Fo}_{78-88}$ cores and $\mathrm{Fo}_{78-83}$ rims (Supplementary Figure 1). Mg-rich cores are often associated with tiny euhedral to podiform crystals of Cr-rich spinels and melt inclusions that are often completely crystallized. Oscillatory zoning is uncommon and remains confined in a narrow compositional range $\left(\mathrm{Fo}_{83-80}\right)$. Olivine micro-phenocrysts are usually more homogeneous than phenocrysts and have cores with composition peaked around $\mathrm{Fo}_{80}$ approximating the composition of phenocryst rims (Figure 8).

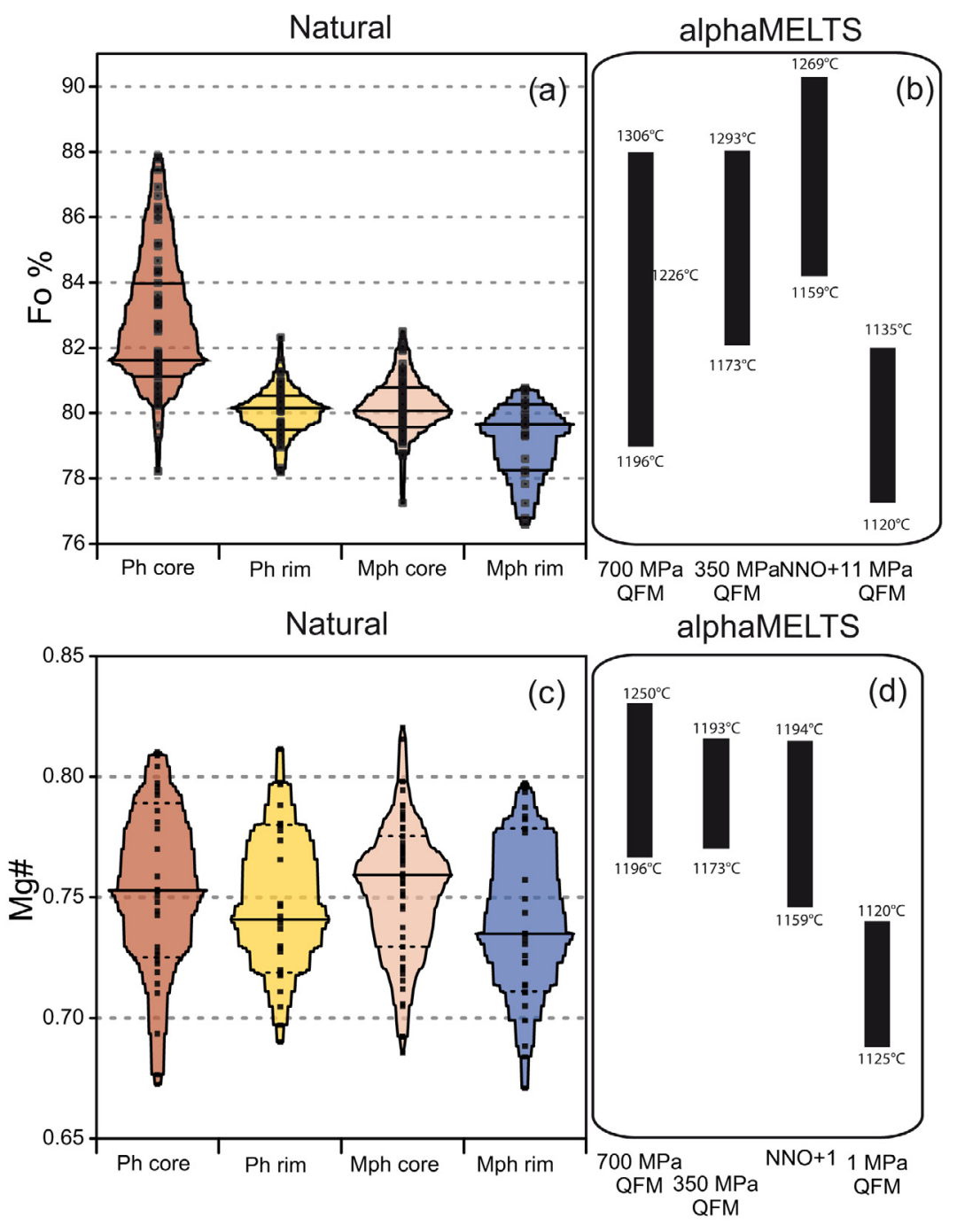

Figure 8. (a-c) Box percentile plots of Forsterite $\%$ and $\mathrm{Mg} \#\left(\mathrm{MgO} / \mathrm{MgO}+\mathrm{FeO}_{\text {tot }}\right.$ on molar basis) respectively in natural olivine and clinopyroxenes erupted during 2011-12 El Hierro eruption grouped on the basis of size of the minerals (Phenocrysts $\geq 500 \mu \mathrm{m}=\mathrm{Ph}$; Microphenocrysts $\leq 500 \mu \mathrm{m}=\mathrm{Mph}$ ) and position (core-mantle and rim). Width of the box is proportional to the distribution height. Median (solid), 25th, and 75th percentiles (dotted) are marked with line segments across the box; (b-d) Range of Forsterite \% and Mg\# composition obtained from thermodynamical modeling of fractional crystallization at different pressure and oxidizing conditions in the reported temperature range. 
Clinopyroxene is the most abundant phase and occurs as phenocrysts, micro-phenocrysts and microlites within the groundmass (Supplementary Figure 1). Phenocrysts are up to $4 \mathrm{~mm}$ and range in morphology from subequant euhedral to subhedral. Microphenocrysts in groundmass range in shape from subequant euhedral and elongated to polyhedral. Groundmass microlites, as large as few microns, are dendritic to skeletal and feathery. Clinopyroxene composition is almost confined within the diopside field, though all crystals exhibit well developed zoning (Figure 8). Patchy and oscillatory zoning is typical of larger phenocrysts whereas sector and hourglass zoning is common in microphenocrysts. Compositional zoning reflects changes in $\mathrm{Mg} \#$ and in the $\mathrm{Ti}, \mathrm{Al}$ and $\mathrm{Si}$ contents. On the whole phenocrysts core and rim show same $\mathrm{Mg} \#$ range on values peaked around 0.75 , while they differ for $\mathrm{Ti} / \mathrm{Si}$ cation ratio. Cores show low values of $\mathrm{Ti} / \mathrm{Si}$ peaked around 0.03 whereas rims exhibit a wider range and are peaked around 0.07 .

Cores in microphenocrysts show $\mathrm{Mg} \#$ values and distribution comparable with those of phenocrysts, with rims extending toward $\mathrm{Mg} \#$ values as low as 0.70 . In addition cores and rims differ for the $\mathrm{Ti} / \mathrm{Si}$ ratio, with rim showing median values of $\mathrm{Ti} / \mathrm{Si}$ higher than in cores.

Spinels occur as $<100 \mu \mathrm{m}$ microphenocrysts and

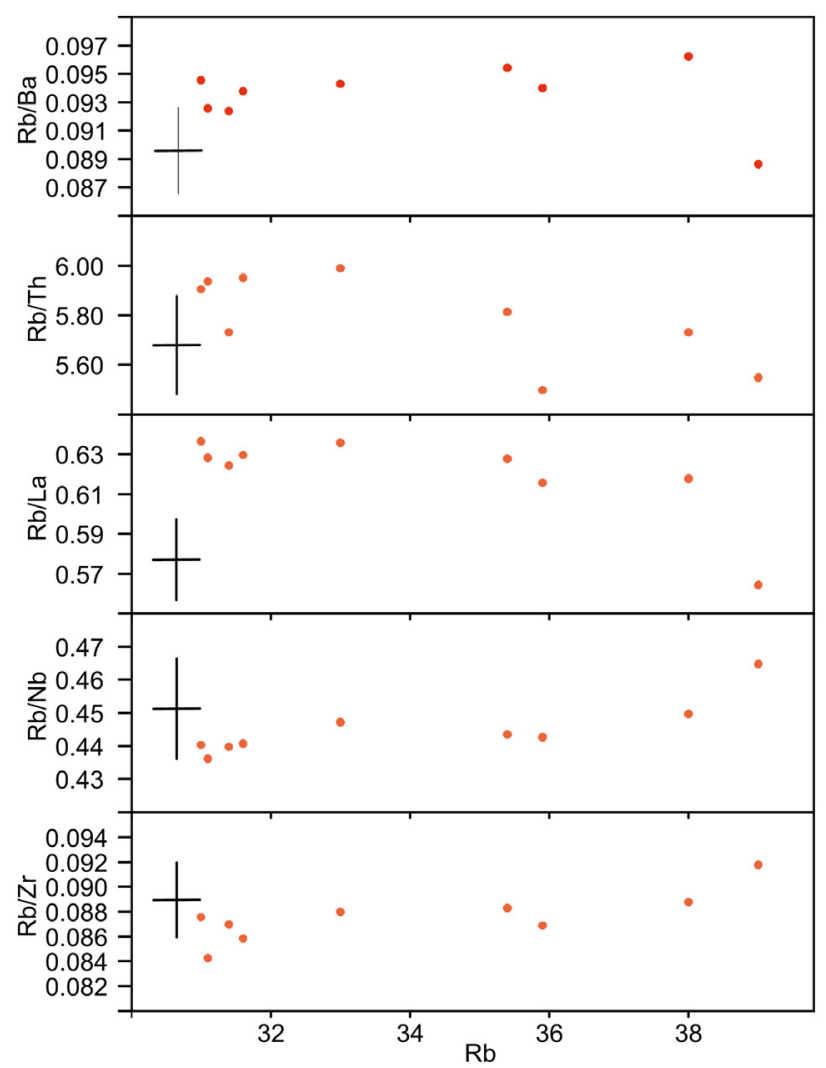

Figure 9. Variation diagrams (unit in $\mathrm{ppm}$ ) for bulk rock $\mathrm{Rb} / \mathrm{Ba}$, $\mathrm{Rb} / \mathrm{Th}, \mathrm{Rb} / \mathrm{La}, \mathrm{Rb} / \mathrm{Nb}$ and $\mathrm{Rb} / \mathrm{Zr}$ ratio versus $\mathrm{Rb}$ during the 201112 El Hierro eruption. Error bars (black crosses) represent 1 sigma. microlites with variable morphologies (Supplementary Figure 1) and comprise minerals belonging to Magnetite-Ulvöspinel series. High-Cr spinels were not found as isolated phenocrysts or microphenocrysts as vice versa reported by Marti et al. [2013b].

Microphenocrysts of plagioclase $<200 \mu \mathrm{m}$ are common only in samples erupted after October 15, 2011. These crystals show mainly an acicular shape (Supplementary Figure 1) with textures typical of fast growth (i.e. swallow-tailed, belt-buckle, chain, acicular bended shape). Their composition ranges between $\mathrm{An}_{60}$ and $\mathrm{An}_{72}$. Few large, 200-300 $\mu \mathrm{m}$ plagioclase crystals occur with patch zoned cores $\left(\mathrm{An}_{51-58}\right)$ as large as few microns and rims with composition $\mathrm{An}_{60-72}$. Plagioclase also form rare holocrystalline aggregates with pyroxene and spinel.

\subsection{Bulk rock and glass composition}

All studied samples have a basanite major element bulk rock composition, with $\mathrm{SiO}_{2}$ ranging between 42.2 and 44.2 wt. \% and alkali content ranging between 5.13 and $6.07 \mathrm{wt}$ \% (Table 3). These compositions overlap those of products emitted during the Quaternary rift volcanism of El Hierro [Carracedo et al. 2001]. In addition, trace element bulk rock composition patterns are fully comparable with those of $\mathrm{El} \mathrm{Hi-}$ erro volcanics showing a relative enrichment of $\mathrm{Th}, \mathrm{Nb}$ and LREE with respect to LILE (Ba, Rb) and following a typical OIB trend and the characteristic pattern of the Canary Island basanites. Bulk rock compositions plot with a limited scatter along a differentiation trend in $\mathrm{CaO} / \mathrm{Al}_{2} \mathrm{O}_{3}$ vs $\mathrm{FeO}_{\text {tot }} / \mathrm{MgO}$ diagram controlled by the precipitation of olivine and clinopyroxene. Glass composition partially overlaps this trend extending toward lower $\mathrm{CaO} / \mathrm{Al}_{2} \mathrm{O}_{3}$ and higher $\mathrm{FeO}_{\text {tot }} / \mathrm{MgO}$ values.

Ratios between highly incompatible trace elements (e.g. $\mathrm{Rb} / \mathrm{Ba}, \mathrm{Rb} / \mathrm{Th}$ and $\mathrm{Rb} / \mathrm{La}$ ) are quite constant with the exception of the sample of October 15, 2011, that slightly exceeds the analytical error accounting for limited contamination of magma by xenopumices. These ratios do not vary with the magma differentiation (Figure 9) pointing to a simple differentiation process starting from a single magma parent and excluding mixing between magma with distinct geochemical features.

Bulk rocks compositions show a progressive and continuous shift toward more mafic compositions starting from the very first day of eruption up to late January (Tables 3 and 4; Figure 10a). In particular the less differentiated samples were emitted on January 28, 2012, whereas the most evolved products were erupted during the first day of eruption, on October 15, 2011. This is witnessed by the regular increase in the $\mathrm{CaO} / \mathrm{Al}_{2} \mathrm{O}_{3}$ 
THE 2011-2012 UNREST AND ERUPTION OF EL HIERRO

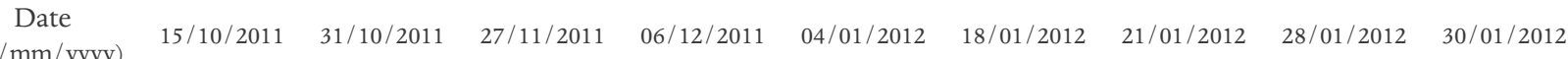
(dd/mm/yyyy)

\begin{tabular}{|c|c|c|c|c|c|c|c|c|c|}
\hline $\mathrm{SiO}_{2}$ & 42.96 & 44.20 & 43.60 & 42.80 & 43.10 & 42.20 & 42.50 & 43.10 & 43.30 \\
\hline $\mathrm{TiO}_{2}$ & 4.28 & 4.42 & 4.74 & 4.70 & 4.70 & 4.50 & 4.61 & 4.76 & 4.69 \\
\hline $\mathrm{Al}_{2} \mathrm{O}_{3}$ & 14.15 & 13.50 & 13.25 & 12.95 & 12.55 & 12.2 & 12.55 & 12.15 & 12.40 \\
\hline $\mathrm{Fe}_{2} \mathrm{O}_{3}$ & 14.42 & 14.75 & 14.40 & 14.15 & 14.35 & 14.45 & 14.75 & 14.35 & 14.20 \\
\hline $\mathrm{CaO}$ & 10.19 & 10.50 & 10.75 & 10.65 & 10.8 & 10.65 & 10.85 & 10.75 & 10.7 \\
\hline $\mathrm{MgO}$ & 6.28 & 7.11 & 7.55 & 7.64 & 8.54 & 8.43 & 8.47 & 8.67 & 8.66 \\
\hline $\mathrm{Na}_{2} \mathrm{O}$ & 4.44 & 3.95 & 4.11 & 4.16 & 3.83 & 4.17 & 3.81 & 3.83 & 4.10 \\
\hline $\mathrm{K}_{2} \mathrm{O}$ & 1.63 & 1.49 & 1.44 & 1.40 & 1.34 & 1.28 & 1.32 & 1.30 & 1.32 \\
\hline $\mathrm{MnO}$ & 0.20 & 0.20 & 0.20 & 0.19 & 0.20 & 0.18 & 0.19 & 0.19 & 0.19 \\
\hline $\mathrm{P}_{2} \mathrm{O}_{5}$ & 1,00 & 0.91 & 0.88 & 0.85 & 0.81 & 0.73 & 0.76 & 0.77 & 0.78 \\
\hline LOI & 0.82 & 0.19 & 0.21 & 0.32 & 0.14 & 1.08 & 0.70 & 0.49 & 0.66 \\
\hline Total & 100.36 & 101.22 & 101.13 & 99.81 & 100.36 & 99.87 & 100.51 & 100.36 & 101,00 \\
\hline $\mathrm{SrO}$ & --- & 0.13 & 0.13 & 0.12 & 0.12 & 0.11 & 0.11 & 0.11 & 0.11 \\
\hline $\mathrm{BaO}$ & --- & 0.05 & 0.06 & 0.05 & 0.05 & 0.04 & 0.04 & 0.05 & 0.05 \\
\hline Cs & 0.5 & 0.47 & 0.41 & 0.39 & 0.4 & 0.34 & 0.35 & 0.36 & 0.37 \\
\hline $\mathrm{Rb}$ & 39 & 38 & 35.9 & 35.4 & 33 & 31 & 31.6 & 31.1 & 31.4 \\
\hline $\mathrm{Ba}$ & 440 & 395 & 382 & 371 & 350 & 328 & 337 & 336 & 340 \\
\hline W & 9.2 & 2 & 1 & 2 & 1 & 1 & 1 & 1 & 1 \\
\hline $\mathrm{Th}$ & 7.03 & 6.63 & 6.53 & 6.09 & 5.51 & 5.25 & 5.31 & 5.24 & 5.48 \\
\hline $\mathrm{U}$ & 1.96 & 1.71 & 1.58 & 1.56 & 1.37 & 1.3 & 1.36 & 1.32 & 1.38 \\
\hline $\mathrm{Nb}$ & 83.9 & 84.5 & 81.1 & 79.8 & 73.8 & 70.4 & 71.7 & 71.3 & 71.4 \\
\hline $\mathrm{Ta}$ & 5.05 & 5.1 & 4.9 & 4.9 & 4.5 & 4.3 & 4.3 & 4.4 & 4.3 \\
\hline $\mathrm{La}$ & 69.1 & 61.5 & 58.3 & 56.4 & 51.9 & 48.7 & 50.2 & 49.5 & 50.3 \\
\hline $\mathrm{Ce}$ & 153 & 128.5 & 122.5 & 118 & 110 & 103.5 & 107.5 & 104.5 & 106.5 \\
\hline $\operatorname{Pr}$ & 18 & 15.6 & 14.9 & 14.45 & 13.45 & 12.5 & 13 & 12.95 & 13 \\
\hline $\mathrm{Sr}$ & 1118 & 1075 & 1025 & 1025 & 960 & 916 & 941 & 932 & 936 \\
\hline $\mathrm{Nd}$ & 73.2 & 64.6 & 62.5 & 61.7 & 56.8 & 53.6 & 55.4 & 54.4 & 55 \\
\hline $\mathrm{Sm}$ & 15.1 & 13.8 & 13.2 & 13.1 & 12.15 & 11.75 & 11.75 & 11.9 & 11.75 \\
\hline $\mathrm{Zr}$ & 425 & 428 & 413 & 401 & 375 & 354 & 368 & 369 & 361 \\
\hline $\mathrm{Hf}$ & 9.3 & 9.8 & 9.4 & 9.4 & 8.8 & 8.4 & 8.5 & 8.9 & 8.5 \\
\hline $\mathrm{Eu}$ & 4.5 & 4.37 & 4.27 & 4.26 & 3.87 & 3.75 & 3.93 & 3.88 & 3.99 \\
\hline $\mathrm{Sn}$ & 3 & 3 & 3 & 3 & 3 & 3 & 3 & 3 & 3 \\
\hline $\mathrm{Gd}$ & 11.3 & 11.7 & 11.65 & 11.6 & 10.15 & 10.45 & 10.45 & 10.3 & 10.6 \\
\hline $\mathrm{Tb}$ & 1.59 & 1.54 & 1.54 & 1.57 & 1.41 & 1.37 & 1.4 & 1.43 & 1.43 \\
\hline Dy & 8.18 & 7.96 & 7.7 & 7.81 & 7.24 & 6.98 & 7.07 & 7.23 & 7.23 \\
\hline $\mathrm{Y}$ & 38.3 & 35.3 & 34.6 & 34.1 & 31.8 & 30.6 & 31.2 & 31.2 & 31.2 \\
\hline Но & 1.36 & 1.36 & 1.33 & 1.36 & 1.23 & 1.21 & 1.22 & 1.2 & 1.21 \\
\hline $\mathrm{Er}$ & 3.41 & 3.2 & 3.13 & 3.2 & 2.94 & 2.77 & 2.86 & 2.81 & 2.92 \\
\hline $\mathrm{Tm}$ & 0.438 & 0.41 & 0.39 & 0.4 & 0.36 & 0.34 & 0.35 & 0.35 & 0.35 \\
\hline $\mathrm{Yb}$ & 2.49 & 2.28 & 2.24 & 2.17 & 2.08 & 1.95 & 1.96 & 1.99 & 1.96 \\
\hline $\mathrm{Lu}$ & 0.354 & 0.31 & 0.32 & 0.31 & 0.28 & 0.27 & 0.28 & 0.27 & 0.27 \\
\hline $\mathrm{Tl}$ & 0.05 & $<0.5$ & $<0.5$ & $<0.5$ & $<0.5$ & $<0.5$ & $<0.5$ & $<0.5$ & $<0.5$ \\
\hline $\mathrm{Ga}$ & 28 & 25.9 & 24.9 & 25.2 & 24.2 & 23.5 & 24.5 & 24.1 & 23.7 \\
\hline $\mathrm{V}$ & 341 & 355 & 367 & 378 & 382 & 373 & 386 & 385 & 381 \\
\hline $\mathrm{Cr}$ & 50 & 140 & 180 & 210 & 280 & 290 & 300 & 290 & 280 \\
\hline
\end{tabular}

Table 3. Bulk rock major and trace elements chemical composition of studied products. 


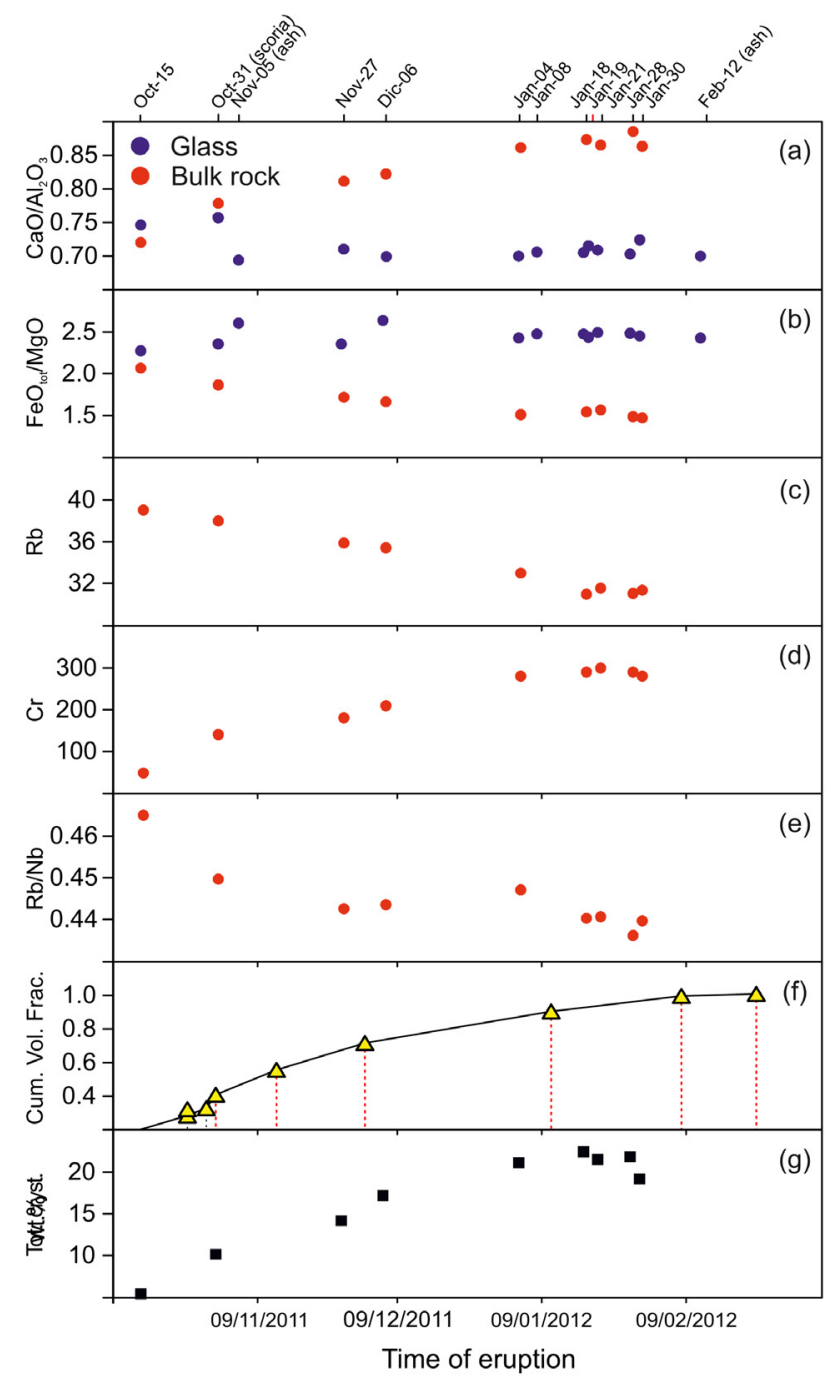

Figure 10. (a) $\mathrm{CaO} / \mathrm{Al}_{2} \mathrm{O}_{3}$ and (b) $\mathrm{FeO}_{\text {tot }} / \mathrm{MgO}$ versus time for bulk rocks (red circles) and glasses (blue circles) composition. (c-e) Temporal variation diagrams of (c) $\mathrm{Rb}$, (d) $\mathrm{Cr}$ and (e) $\mathrm{Rb} / \mathrm{Nb}$ ratio (unit in $\mathrm{ppm}$ ). (f) cumulative volume fraction (yellow triangles) of erupted material after Rivera et al. [2013] and (g) total crystallinity (wt.\%) obtained by mass balance calculation between bulk rocks and glass considering the average composition of minerals.

Table 4 (left). Mean glass composition of studied products with standard deviation values.

value and in the content of compatible elements (e.g. $\mathrm{Cr}$; Figure 10d) and by the decrease in the $\mathrm{FeO}_{\text {tot }} / \mathrm{MgO}$ value (Figure 10b) and in the content of incompatible elements (e.g. Rb; Figure 10c).

On the contrary, composition of glass is almost homogeneous during the entire eruption (Table 4 and Figure 10a and $\mathrm{b}$ ), and approximates the composition of bulk rocks erupted during the first two weeks of eruption (samples of October 15 and 31, 2011).

Also ratio between highly incompatible elements (e.g. $\mathrm{Rb} / \mathrm{Nb}$ reported in Figure 9) remains constant (within the analytical error range) during the whole eruption, this once again indicates that the magma feeding the eruption maintains homogeneous geochemical signature. 


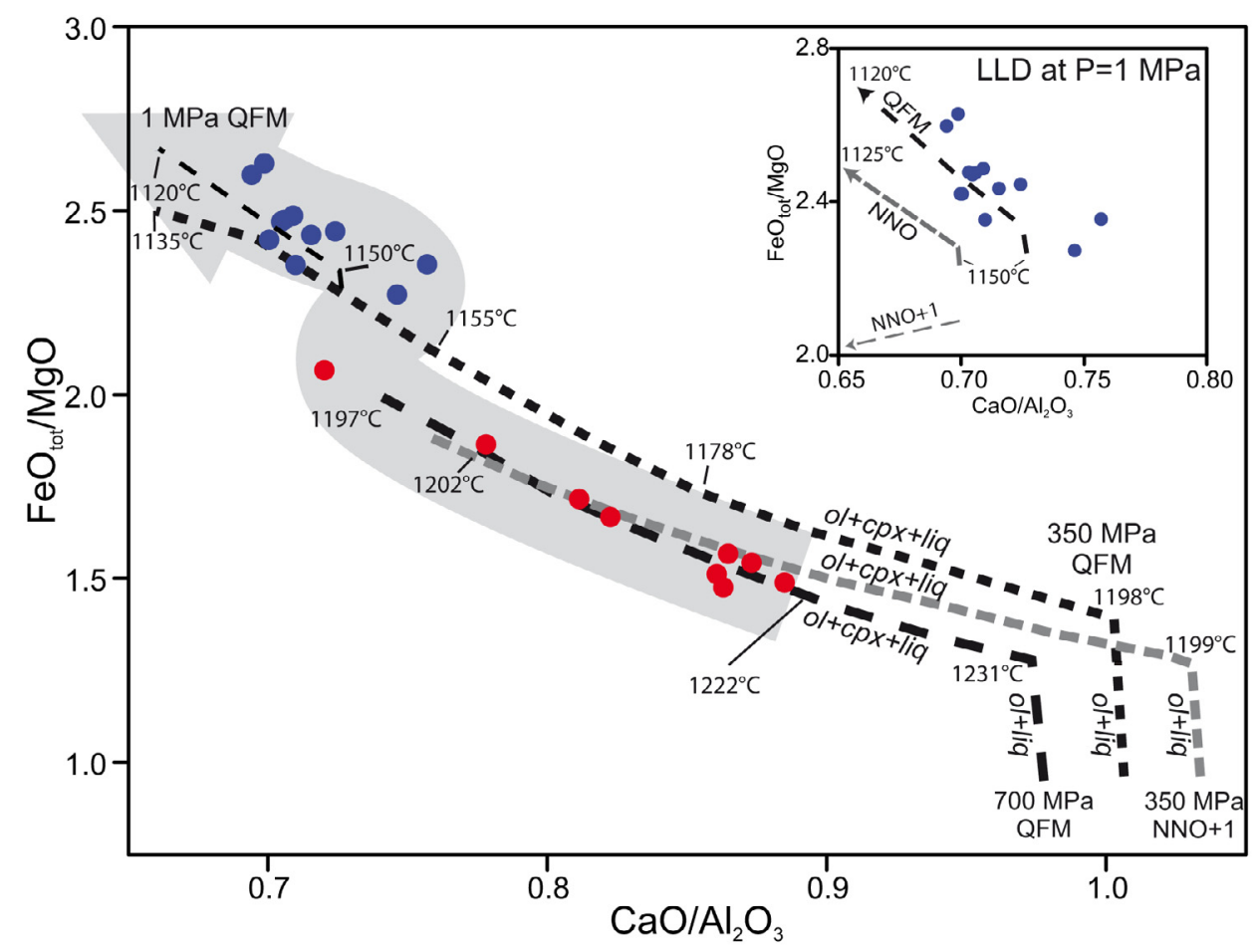

Figure 11. Comparison between compositions of bulk rocks (red solid circles), glass (blue solid circles) and liquid lines of descent (LLD) obtained by thermodynamic modeling of cooling (range of temperature are reported) and fractional crystallization at different pressures (700$1 \mathrm{MPa}$ ) under distinct oxidation conditions (from QFM to NNO+1). Gray arrow describe possible ascent path of magma that starts to crystallize at $700 \mathrm{MPa}$ (between 1300 and $1200^{\circ} \mathrm{C}$ under QFM) or at $350 \mathrm{MPa}$ (between 1199 and $1160^{\circ} \mathrm{C}$ under NNO+1), moves at lower pressure and finally quench at temperatures between $1150^{\circ} \mathrm{C}$ down to $1120^{\circ} \mathrm{C}$, close to the surface. Inset shows liquid line of descent at $\mathrm{P}=$ $1 \mathrm{MPa}$ (water depth of $100 \mathrm{~m}$ ) under different oxidizing conditions and glass compositions measured during the 2011-12 El Hierro eruption.

\subsection{Thermodynamic modeling}

Large variations in bulk rocks composition accompanied by variability in crystal content and significant zoning in crystals possibly indicates that magma experienced several magmatic environments and complex magmatic processes along the ascent. As a consequence, thermodynamic modeling techniques [Ghiorso and Sack 1995] have been employed to track the whole history of the magma, using a combination of geophysical and petrological data as initial and as boundary conditions.

Relocated depths of hypocentral foci by Domínguez Cerdeña et al. [2014] and local lithosphere and density structure [Collier and Watts 2001] have been used as first guesses to constrain pressure ranges where magma might have resided before the eruption. Accordingly, we simulated cooling and crystallization of mantle derived melts respectively in a deep magmatic reservoir at mantle pressure of $700 \mathrm{MPa}$ (corresponding to a seismic source at $20-25 \mathrm{~km}$ ) and in a crustal storage zone at pressure of $350 \mathrm{MPa}$ (corresponding to a seismic source at $8-12 \mathrm{~km}$ ). Final cooling at pressure of $1 \mathrm{MPa}$ corresponding to water column of about $100 \mathrm{~m}$ has been also modeled. We selected as starting material a magma with the composition equal to that of rocks erupted on October 31, 2011. In fact in these samples the compositions of glass and bulk rock almost match, thus indicating that this sample possibly represents a magmatic liquid. From this starting composition we estimated the composition of a parental liquid in equilibrium with mantle conditions using the Amoeba routine of AlphaMELTS [Smith and Asimov 2005]. This routine varies the parental melt composition until isobaric forward fractionation yields a specified target (here considered as the composition of October 31, 2011). From this parental melt we simulated, again using AlphaMELTS, an isobaric cooling and crystal fractionation processes at 700, 350 and $1 \mathrm{MPa}$ under distinct $\mathrm{fO}_{2}$ paths variable from 1 log unit more oxidizing than those of the NiNiO buffer from $(\mathrm{NNO}+1)$ to QFM (quartz-fayalite-magnetite) redox buffers. In this way we were able to investigate and reproduce the liquid line of descent (LLD) of the whole suite from the mantle to the final stages of the ascent, through crustal magma storage. Comparison between simulated liquid line of descent and composition of erupted products is shown in $\mathrm{CaO} / \mathrm{Al}_{2} \mathrm{O}_{3}$ vs $\mathrm{FeO}_{\text {tot }} / \mathrm{MgO}$ diagram of Figure 11. Bulk rocks compositions match the evolution of magma precipitating olivine $\mathrm{Fo}_{85-81}$ and clinopyroxene with $\mathrm{Mg} \#=0.80-0.77$ at $\mathrm{P}=700 \mathrm{MPa}$, at temperatures between 1220 and $1190^{\circ} \mathrm{C}$ and under a QFM buffer. The same compositional trend is also compatible with the cooling of a magma and crystallization of olivine $\mathrm{Fo}_{87-84}$ and clinopyroxene with $\mathrm{Mg \#}=0.80-0.74$ 
at temperature between 1180 and $1160^{\circ} \mathrm{C}$ and at $\mathrm{P}=$ $350 \mathrm{MPa}$ under $\mathrm{NNO}+1$ buffer.

Glass compositions plot across the liquid line of descent resulting from crystallization of the same phases (olivine $\mathrm{Fo}_{80-79}$ and clinopyroxene with $\mathrm{Mg} \#=$ 0.74-0.73) plus spinel at $350 \mathrm{MPa}$ between $1155-1150^{\circ} \mathrm{C}$ and at $1 \mathrm{MPa}$ between 1145 to $1120^{\circ} \mathrm{C}\left(\mathrm{Fo}_{79-77} ; \mathrm{Mg} \#\right.$ 0.70-0.69) under QFM redox conditions. Composition of precipitated phases in equilibrium (Figure 8) match the range observed in natural products.

Comparisons between liquid line of descent, mineral composition calculated by thermodynamic modeling and compositional variations observed in bulk rocks and glasses show that:

- assuming a parental magma in equilibrium with a mantle mineral assemblage, as that retrieved by alphaMELTS, large part of the crystallization $(\approx 50 \%)$ is controlled by phase equilibria that occur in a storage system that result to be very deep in case of reducing condition (located in the mantle at $700 \mathrm{MPa}$ at $\mathrm{fO}_{2}=$ QFM) or in the crust if oxidizing condition are considered (at $350 \mathrm{MPa}$ and $\mathrm{fO}_{2}=\mathrm{NNO}+1$ ). Glass composition reflects final precipitation $(\approx 5 \%)$ during the quenching in the last stage of the ascent;

- irrespective of the relative depths, the vertical extent of the storage system where precipitation of minerals occur, should be limited since the scattering of natural sample composition along isobaric curves is very small;

- considering even the early phase of crystallization in which only olivine is on the liquidus, large part of the cooling $\left(1300-1150^{\circ} \mathrm{C}\right)$ occurs at pressure higher than $350 \mathrm{MPa}$ and the last temperature $\operatorname{drop}\left(\approx 30^{\circ} \mathrm{C}\right)$ takes place only during the final stage of the ascent to the surface.

\section{Discussion}

6.1. Ascent dynamics from geophysical and geodetical constraints

\subsubsection{Pre-eruptive (July-October 2011)}

In the first period of the unrest crisis, until early September, geophysical and geodetical signals indicate that magma was emplacing within the lower crust or close to the Moho discontinuity that for Canary Islands is estimated to be at $13-16 \mathrm{~km}$ of depth [Carracedo 1994, Ranero et al. 1995, Lodge et al. 2012, López et al. 2012]. The distribution and the low-magnitude of seismic events, as well as ground deformation pattern, suggest that small-volume intrusions of magma took place at $8-12 \mathrm{~km}$ of depth in the center, center-south sectors of the island. The geometry of the intrusions was pos- sibly controlled by preexisting intrusive complexes and zones of structural weakness as those revealed by recent magnetic, gravimetric and structural studies [Montesinos et al. 2006, Blanco-Montenegro et al. 2008, García-Yeguas et al. 2012, González et al. 2013, Gorbatikov et al. 2013, García-Yeguas et al. 2014]. The lowmagnitude earthquakes occurred during this phase could be related to the expansion of magma or magmatic fluids within this preexisting fractures system [Hill 1977, Roman et al. 2006]. In addition, the spatial distribution and temporal evolution of the hypocenters, their tight clustering as well as GPS data suggest that magma propagated in different direction possibly as fingers [Pollard et al. 1975, Schofield et al. 2010] characterized by small volume and not capable of generating new fractures inside the volcanic edifice [Gudmundsson and Løtveit 2005].

The drastic change both in the seismicity and ground deformation pattern occurred on early September likely indicates a change in the dynamics of magma movement. Since the volume of magma tapped cannot be accounted by the fracture system that was used in the earlier intrusions, magma started to migrate at depth and southward following zones of structural weakness. Although this migration in depth was interpreted as a "faulty" migration, due to the Moho anomaly [Ibañez et al. 2012], after relocation of seismic events it was clear that it represents a real migration with the hypocenters marking tight clusters. This migration was in the order of $10 \mathrm{~km}$.

Seismic and ground deformation data indicate that ten days before the onset of the eruption, a storage system was emplaced at depth (12-16 km), off the coast of El Julan. This is in agreement with evidence resulting by Interferometric Synthetic Aperture Radar (InSAR) observations of González et al. [2013] and as a whole, with results of analysis of seismic and ground deformation data of García et al. [2014]. The 12 hours of seismic silence occurred between the major $\mathrm{ML}=4.3$ earthquake and the sudden appearance of seismic multiplets at $<3 \mathrm{~km}$ of depth close to the future vent was previously interpreted as an extremely rapid $\left(0.13 \mathrm{~ms}^{-1}\right.$; Martí et al. [2013a]), aseismic magma ascent [Ibáñez et al. 2012] whereas the major event was interpreted as the beginning of the ascent [Martí et al. 2013a, 2013b].

We suggest that the seismic silence and seismic activity at shallow depth might occur when the ascending magma found a ductile zone represented by a stagnant magma pocket/s and hydrothermally altered volcanic rocks [Meletlidis et al. 2012, Sigmarsson et al. 2012, Del Moro et al. 2015]. The interaction (heating/pyrometamorphism) between the basanitic magma feeding the eruption, and the rocks/magma of the duc- 
tile zone would have initially resulted in an almost aseismic, horizontal expansion of the magma and later in the shallow seismicity. Similar processes have been described in volcanic rift zones of Kilauea [Rubin et al. 1998] and Krafla volcano in Iceland [Einarsson and Brandsdóttir 1980] or for Paricutin volcano [Gardine et al. 2011]. Materials resulting from the interaction of basaltic magma feeding the eruption and preexistent magma pocket/s and hydrothermally altered volcanic rocks were emitted during the first day of the eruption [Meletlidis et al. 2012, Sigmarsson et al. 2012, Del Moro et al. 2015].

\subsubsection{Syn-eruptive (October 2011-March 2012)}

The relatively low magnitude, shallow seismicity at depth of $10-14 \mathrm{~km}$ that was registered for about 20 days after the onset of the eruption and again from early January to March 2012, is interpreted here as the readjustment of the stress field nearby the vent and the relaxation of the host rock when finally the eruption ceased, respectively.

Our analysis of seismic data indicates that the deep seismicity in the northern part of the island persisted far longer than previously proposed by Martì et al. [2013a] and consisted in two distinct swarms the first at 20-25 km since October 18 and the second, starting one week later at $15-20 \mathrm{~km}$, respectively. The tendency of these two seismic swarms (a progressive increase in the number and magnitude of the events over a few days culminating in larger seismic events and finally followed by a drop in both the parameters) is almost identical to
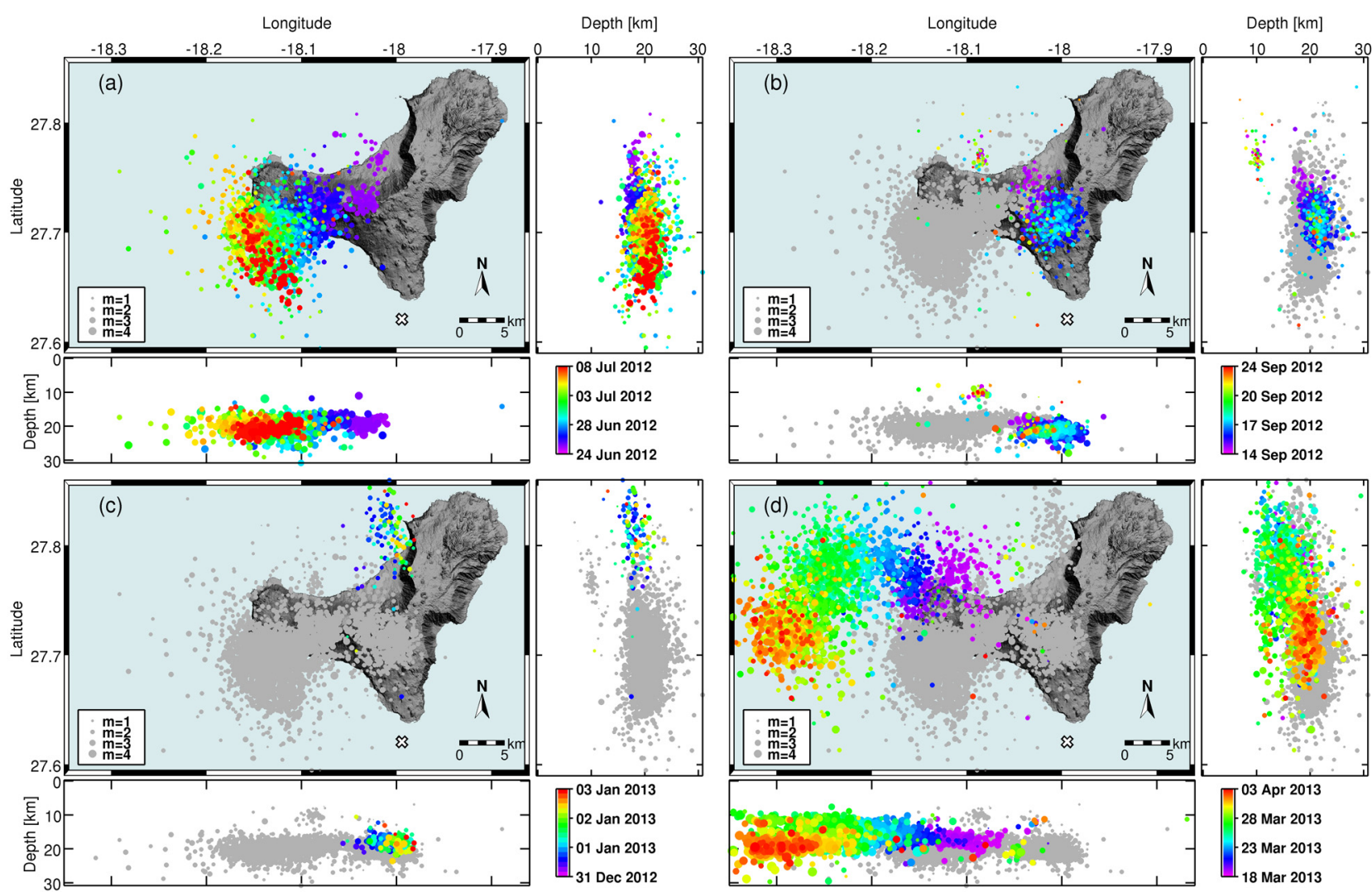
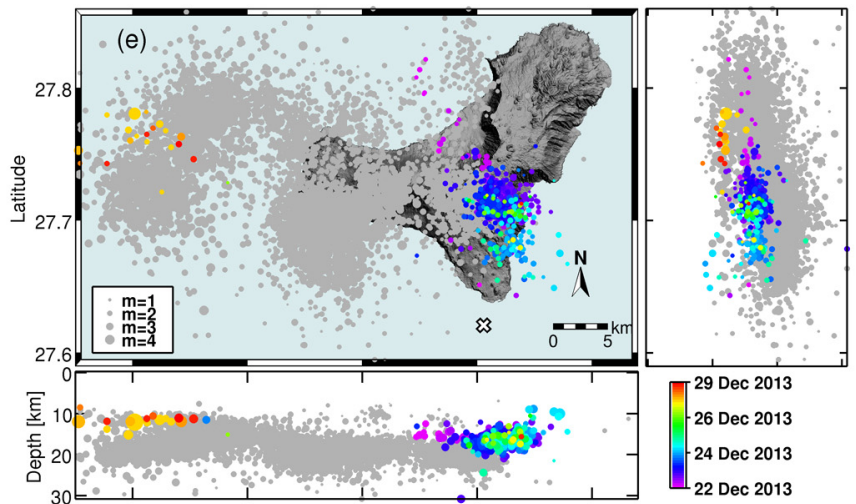

26 Dec 2013

$24 \operatorname{Dec} 2013$

22 Dec 2013

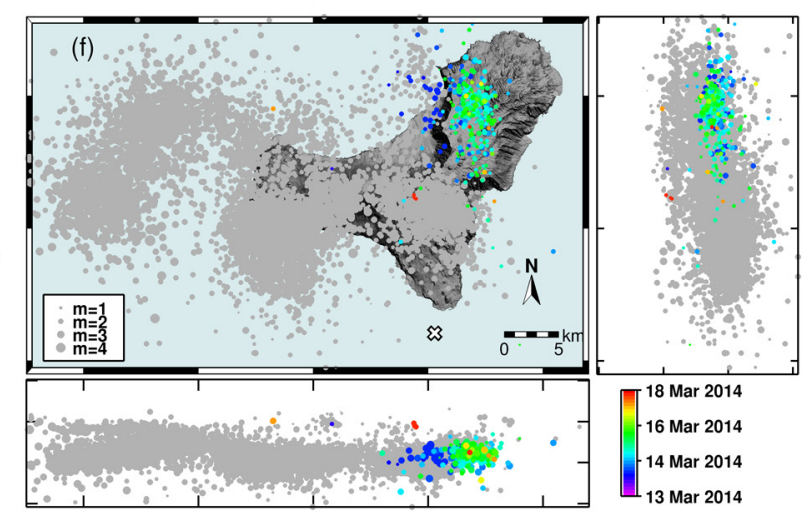

Figure 12. Temporal evolution of the latitude, longitude and depth $(\mathrm{km})$ of the earthquakes for the six distinct seismic episodes occurred after the end of 2011-2012 El Hierro eruption (time scale of events is reported in the color bar; in grey are reported earthquakes occurred in the previous seismic episodes). 
that of several seismic swarms occurred on the island after the end of the eruption (Figure 12).

Our data show that seismic activity does not correlate with appreciable ground deformation changes. No significant deflation of the whole island was detected as should be expected in case of a deep magma chamber depressurization. In fact, no changes in the horizontal components (northing and easting) of deformation were registered after the onset of the eruption (unless negligible fluctuations) and relative high $(2 \mathrm{~cm})$ vertical deflation was registered only by two stations, close the eruptive site (HI09 in La Restinga and HI10 in Tacoron bay) and one (FRON) in El Golfo depression. This, according to Prates et al. [2012], may indicate that the source of deformation was not horizontally distant from the station where deformation was recorded. Thus, the high vertical deformation may be due to a local perturbation of the system e.g. the presence of pressurized magmatic gas close to the deformation site. We propose that a possible mechanism for generating the deep seismicity occurred after October 2011 (two swarms during the eruption and seven more after up to the moment of this writing) is the emplacement of magma at depth without significant deflation of the plumbing system. This is in agreement with conclusions presented by García et al. [2014]. A similar event could have occurred in 1793 , when a strong seismic crisis did not result in a volcanic eruption at least subaerial [Villasante-Marcos and PavónCarrasco 2014].

\subsection{Ascent dynamics and magma evolution from petro-} logical data

We observed that the bulk rocks compositions varied significantly during the eruption with a progressive and continuous shift towards more mafic term (Figure 10a). Such variation can be accounted by crystals fractionation and crystals cumulus of mafic phases, which increase from $5 \mathrm{wt}$. \% in the first day of the eruption up to ca. 20 wt. \% in January (Figure $10 \mathrm{~g}$ ).

Although thermodynamic modeling cannot discriminate if this process occurs in the mantle reservoir at $\mathrm{P}=700 \mathrm{MPa}$ under reduced $\mathrm{fO}_{2}(\mathrm{QFM})$ or at crustal levels at $\mathrm{P}=350 \mathrm{MPa}$ under more oxidized conditions $\left(\mathrm{fO}_{2}=\mathrm{NNO}+1\right)$, the observed compositional variations imply the existence of a zoned magma body that is progressively withdrawn during the eruption. The overall constancy of highly incompatible elements ratio (e.g. $\mathrm{Rb} / \mathrm{Nb}, \mathrm{Rb} / \mathrm{Th}, \mathrm{Rb} / \mathrm{Lb}$ and $\mathrm{Nb} / \mathrm{La}$ ) versus time indicates that the process of magma differentiation responsible of such a zoning operated from a single parental magma. This interpretation differs from those previously proposed by Martí et al. [2013a, 2013b] and Long- pré et al. [2014].

Longpré et al. [2014], on the basis of Cpx-melt geobarometry, point to the occurrence of two distinct storage zones in comparable shallow mantle depths in the same pressure range (500-710 MPa) that we investigated with our thermodynamic modeling. They also propose that magmas supplied from these distinct reservoirs mix and homogenize shortly prior to their ascent into a third storage zone within the lower crust.

Mixing evidences of Longpré et al. [2014] are mainly based on the occurrence of a) differentiated liquids found as melt inclusions (MI) in Fe-Ti oxides and b) slight reversed zoning in olivine with core $\mathrm{Fo}_{78}$ and rims $\mathrm{Fo}_{80}$. Differentiated liquids as those reported in MI by Longpré et al. [2014] implies a correspondent mineral assemblage (e.g. Fo $<78)$ that is not found in El Hierro 2011-12 samples. Notably slight reversed zoning in olivine can also form as result of migration of crystal between compositionally and thermally distinct regions of a cooling and crystallizing magma body [Kahl et al. 2011]. Differences of this amplitude would correspond to temperature differences of few tens of degrees as shown by Martí et al. [2013b] and are compatible with thermal gradient within a zoned magma chamber.

Thus, while we can agree that limited mixing processes may have occurred within this deep evolving storage due to convective circulation, we think that large-scale mixing process involving two reservoirs is unlikely since it is incompatible with regular compositional variations that we observed during the eruption. In fact, the full re-homogenization before the ascent and emplacement in a third crustal storage (10-15 km) would have been followed by an additional process of segregation and cumulus of mafic phases during the syn-eruptive ascent, in order to account for the regular variation observed in bulk rock composition.

Martí et al. [2013a, 2013b] indicate that magma differentiation occurs mainly in the crustal reservoir and show that a recharge event of the shallow magmatic system occurred on early December, 2011, with fresh magma coming from a deeper reservoir. This was proposed on the basis of an observed drop in crystallinity and a change in bulk rock composition between the sample of November 27 and that of December 5, 2011. According to the authors, the December sample (with crystallinity $\sim 20$ wt. $\%, \mathrm{SiO}_{2}=43.76$ wt. $\%$ and $\mathrm{FeO}_{\text {tot }}=$ 12.85 wt. \%) marked the arrival of the second magma batch and the November sample (characterized by a considerably higher crystal content of ca. 50 wt. \%, $\mathrm{SiO}_{2}=40.31$ wt. $\%$ and $\left.\mathrm{FeO}_{\text {tot }}=17.07\right)$ is considered the last product of the first magma batch. However, it should be noted that the sample HB5 of Martí et al. [2013a, 2013b] collected on November 27 shows an 
anomalous composition if compared to the products of the same day analyzed in this work and in Longpré et al. [2014]. In particular, the high $\mathrm{FeO}_{\text {tot }}$ content of ca. 17 wt. \% is not consistent with the content of $\mathrm{MgO}$, which is instead rather comparable with that of the other samples. This high value of $\mathrm{FeO}_{\text {tot }}$ is found in the Canary Islands only for plutonic rock (e.g. gabbro, pyroxenite and horneblendite; GEOROC-Geochemistry of Rocks of the Oceans and Continents, http:/ / georoc. mpch-mainz.gwdg.de). Thus, we suppose that crystallinity and composition of the sample HB5 of Martí et al. [2013a, 2013b] is not representative of the real magma emitted in that day, possibly for the presence of a xenolith (cumulate rock) or recycled material, and cannot be used for petrological reconstruction and modeling.

\section{Conclusive remarks}

Results of the temporal analysis of seismic events, ground deformation patterns and gravity data as well as of the texture and composition of mineral phases, bulk rock and volcanic glass contribute to give new clues on the 2011-2012 eruption at El Hierro Island.

According to geophysical and geodetical data the eruption was driven by a stepwise migration of a batch of magma between three main magmatic environments, including a deep reservoir, a crustal magma reservoir and a final shallow conduit and vent zone (Figure 13). Initially, the magma emplaced in an indefinite time in deep magma chamber possibly located in the upper mantle. Later magma ascended aseisimically to the lower crust and on July 2011 reached the depth of 8-12 $\mathrm{km}$. Here magma initially propagated as small-volume fingers or lobes not capable of generating new fractures inside the volcanic edifice. Magma path was initially controlled by preexisting intrusive complex and zones of structural weakness within the edifice resulting in a typical distribution of earthquakes. On September 2011 the magma migrated at depth and southward forming a storage system off the coast of El Julan and causing seismic activity at depth of $12-16 \mathrm{~km}$. Petrological data indicate that the eruption was fed by a single magma whose composition varied trough a dominant process of crystals fractionation and crystals cumulus of mafic phases. However, thermodynamic modeling cannot discriminate if this process occurs in the mantle reservoir or in the crustal storage zone.

After a period of stagnation of about a month, the magma rapidly ascended to the final eruptive site suffering only a minor quenching and crystallization of clinopyroxene, olivine and plagioclase. Final aseismic ascent likely occurred trough relatively weak paths. The
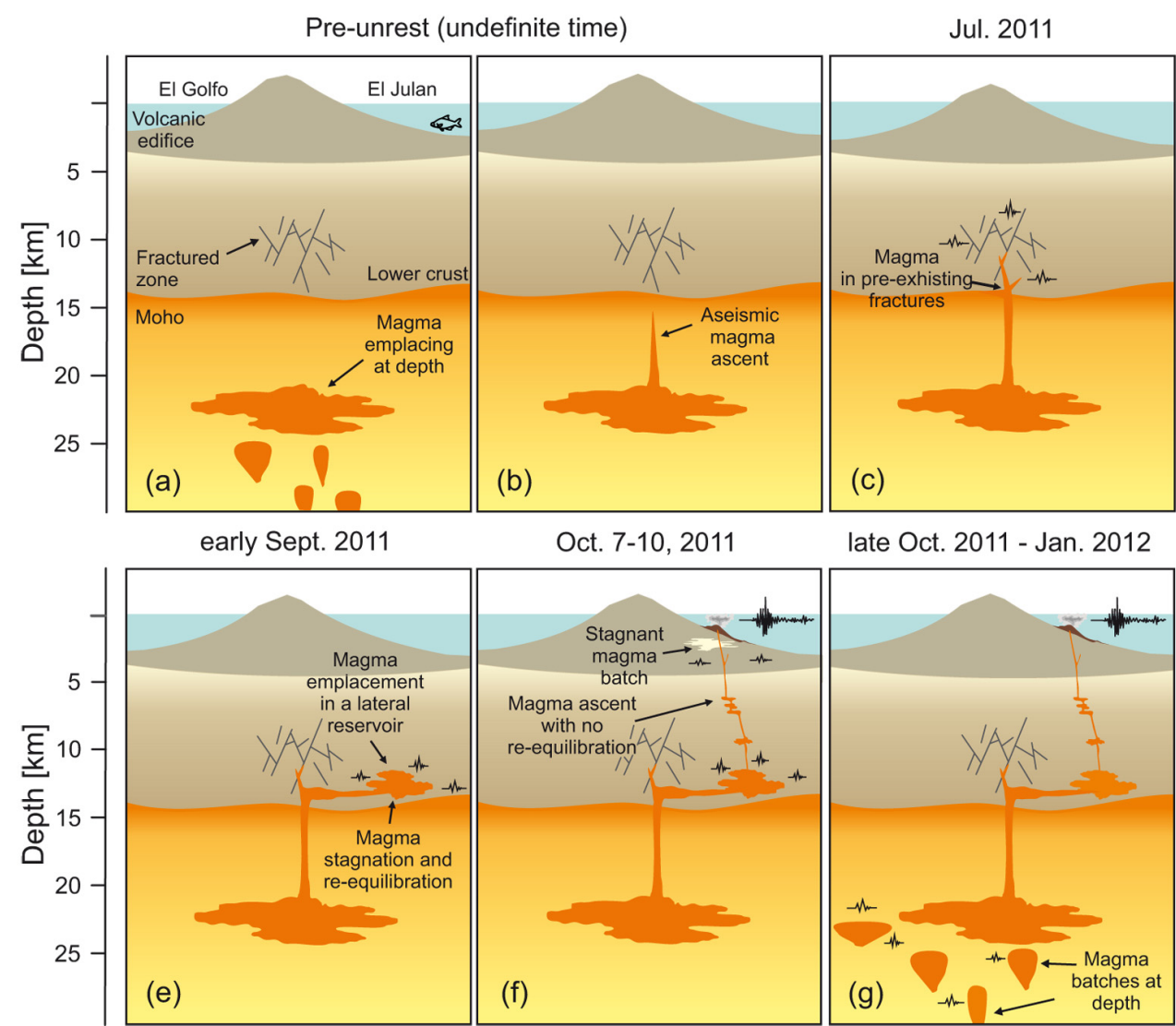

early Sept. - early Oct., 2011
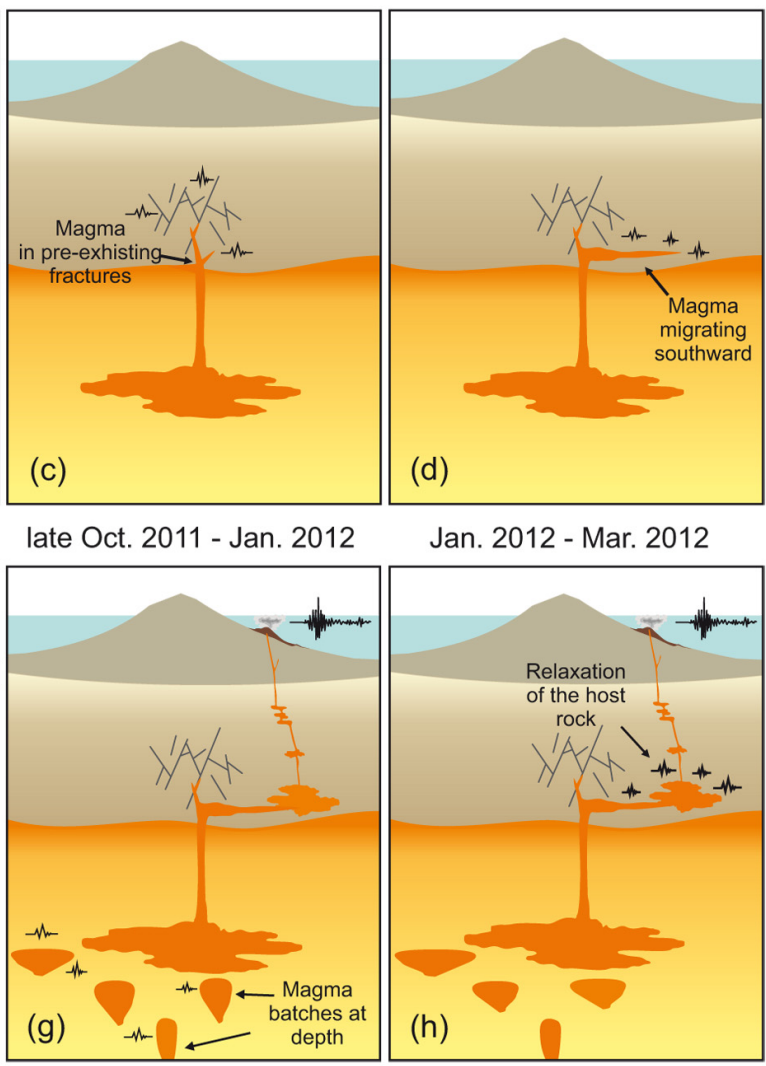

Figure 13. Cartoon interpretation (not to scale) of the volcanic system activated in El Hierro Island during the 2011-2012 unrest and eruption (along a north-south cross section). Panels $(\mathrm{a}-\mathrm{h})$ show in brief the main events that led to the eruption that were discussed in the text. 
stepwise ascent of magma of relatively small volume magma pockets (likely in the form of interconnected dyke and sills) is in agreement with that proposed by Stroncik et al. [2009] for El Hierro and other intraplate volcanoes, which includes multistage magma ascent with major crystal fractionation in the uppermost mantle and short-term stagnation at shallower levels.

Acknowledgements. We would like to thank the Volcano Monitoring Group (IGN) for the deployment and maintenance of the seismic and GPS networks along with the gravimetric station on El Hierro. Special thanks are due to the Sociedad de Salvamento y Seguridad Marítima (SASEMAR) for the efforts in sampling (without the personnel and its infrastructure sampling wouldn't have been possible) and the Municipality of El Pinar (especially to Mr. Jesus Pérez Quintero) for their help on logistics. This work was funded by the National Geographical Institute of the Spanish Ministerio de Fomento. We also would like to thank GRAFCAN for the open and free access to the GPS station of FRON and to UCA-CSIC for the data of the HI00 station that was used in the framework of the CSIC-IGN scientific collaboration and advice agreement (20062012). ADR was supported by DPC-INGV V1 agreement. The data for this paper are property of Instituto Geográfico Nacional, Spain and can be explored and downloaded on request at www.ign.es. Two anonymous reviewers and Editor F. Bianco are kindly acknowledged for their constructive revision of the manuscript.

\section{References}

Acosta, J., E. Uchupi, D. Smith, A. Muñoz, P. Herranz, C. Palomo, P. Llanes, M. Ballesteros and ZEE Working Group (2003). Comparison of volcanic rifts on La Palma and El Hierro, Canary Islands and the Island of Hawaii, Mar. Geophys. Res., 24, 59-90; doi:10.1007/s11001-004-1162-6.

Blanco-Montenegro, I., I. Nicolosi, A. Pignatelli and M. Chiappini (2008). Magnetic imaging of the feeding system of oceanic volcanic islands: El Hierro (Canary Islands), Geophys. J. Int., 173, 339-350; doi:10. 1111/j.1365-246X.2008.03723.x.

Carracedo, J.C. (1994). The Canary Islands: an example of structural control on the growth of large oceanisland volcanoes, J. Volcanol. Geoth. Res., 60, 225241; doi:10.1016/0377-0273(94)90053-1.

Carracedo, J.C., E.R. Badiola, H. Guillou, L. De La Nuez and F.J. Perez Torrado (2001). Geology and volcanology of La Palma and El Hierro, western Canaries, Est. Geol., 57, 175-273.

Collier, J.S., and A.B. Watts (2001). Lithospheric response to volcanic loading by the Canary Islands: constraints from seismic reflection data in their flexural moat, Geophys. J. Int., 147, 660-676; doi:10.1046/ j.0956-540x.2001.01506.x.

Del Moro, S., A. Di Roberto, S. Meletlidis, M. Pompilio, A. Bertagnini, S. Agostini, F. Ridolfi and A. Renzulli (2015). Xenopumice erupted on 15 October 2011 offshore of El Hierro (Canary Islands): a subvolcanic snapshot of magmatic, hydrothermal and pyrometa- morphic processes, B. Vulcanol., 77 (6), 53; doi:10. 1007/s00445-015-0940-0.

Domínguez Cerdeña, I., C. del Fresno and A. Gomis Moreno (2014). Seismicity patterns prior to the 2011 El Hierro Eruption, B. Seismol. Soc. Am., 104 (1), 567-575; doi:10.1785/0120130200.

Einarsson, P., and B. Brandsdóttir (1980). Seismological evidence for lateral magma intrusion during the July 1978 deflation of the Krafla volcano in NE-Iceland, J. Geophys., 47, 160-165; doi:10.2172/890964.

García, A., A. Fernandez-Ros, M. Berrocoso, J.M. Marrero, G. Prates, S. De la Cruz-Reyna and R. Ortiz (2014). Magma displacements under insular volcanic fields, applications to eruption forecasting: El Hierro, Canary Islands, 2011-2013, Geophys. J. Int.; doi:10.1093 / gji/ggt505.

García-Yeguas, A., I. Koulakov, J.M. Ibáñez and A. Rietbrock (2012). High resolution 3D P-wave velocity structure beneath Tenerife Island (Canary Islands, Spain) based on tomographic inversion of activesource data, J. Geophys. Res., 117; doi:10.1029/2011 JB008970.

García-Yeguas, A., J.M. Ibáñez, I. Koulakov, A. Jakolev, M.C. Romero-Ruiz and J. Prudencio (2014). Seismic tomography model reveals mantle magma sources of recent volcanic activity at El Hierro Island (Canary Uslands, Spain), Geophys. J. Int., 199, 17391750; doi:10.1093 / gij/ggu339.

Gardine, M., M.E. West and T. Cox (2011). Dike emplacement near Parícutin volcano, Mexico in 2006, B. Volcanol., 73, 123-132; doi:10.1007/s00445-0100437-9.

Ghiorso, M.S., and R.O. Sack (1995). Chemical MassTransfer in Magmatic Processes IV. A Revised and Internally Consistent Thermodynamic Model for the Interpolation and Extrapolation of Liquid-Solid Equilibria in Magmatic Systems at Elevated-Temperatures and Pressures, Contrib. Min.Pet., 119 (23), 197-212; doi:10.1007/BF00307281.

González, P.J., S.V. Samsonov, S. Pepe, S.F. Tiampo, P. Tizzani, F. Casu, J. Fernández, A.G. Camacho and E. Sansosti (2013). Magma storage and migration associated with the 2011-2012 El Hierro eruption: Implications for crustal magmatic systems at oceanic island volcanoes, J. Geophys. Res. Solid Earth, 118, 1-17; doi:10.1002/jgrb.50289.

Gorbatikov, A.V., F.G. Montesinos, J. Arnoso, M.Y. Stepanova, M. Benavent and A.A. Tsukanov (2013). New Features in the Subsurface Structure Model of El Hierro Island (Canaries) from Low-Frequency Microseismic Sounding: An Insight into the 2011 Seismo-Volcanic Crisis, Surv. Geophys., 34, 463-489; doi:10.1007/s10712-013-9240-4. 
Gudmundsson, A., and I.F. Løtveit (2005). Dyke emplacement in a layered and faulted rift zone, J. Volcanol. Geotherm. Res., 144 (1), 311-328; doi:10.1016/ j.jvolgeores.2004.11.027.

Guillou, H., J.C. Carracedo, F. Pérez Torrado and E. Rodríguez Badiola (1996). K-Ar ages and magnetic stratigraphy of a hotspot-induced, fast grown oceanic island: El Hierro, Canary Islands, J. Volcanol. Geoth. Res., 73, 141-155; doi:10.1016/03770273(96)00021-2.

Gutenberg, B., and C. Richter (1954). Seismicity of the Earth and Associated Phenomena (Princeton University Press, Princeton, New Jersey), 2nd ed., 310 p. Hill, D.P. (1977). A model for earthquake swarms, J. Geophys. Res., 82, 1347-1352; doi:10.1029/JB082i00 8 p01347.

Ibáñez, J.M., S. De Angelis, A. Díaz-Moreno, P. Hernández, G. Alguacil, A. Posadas and N. Pérez (2012). Insights into the 2011-2012 submarine eruption off the coast of El Hierro (Canary Islands, Spain) from statistical analyses of earthquake activity, Geophys. J. Int., 191, 659-670; doi:10.1111/j.1365-246X.2012.056 29.x.

Kahl, M., S. Chakraborty, F. Costa and M. Pompilio (2011). Dynamic plumbing system beneath volcanoes revealed by kinetic modeling, and the connection to monitoring data: An example from Mt. Etna, Earth Plan. Sci. Lett., 308, 11-22; doi:10.1016/j.epsl. 2011.05.008.

Lodge, A., S.E.J. Nippress, A. Rietbrock, A. GarcíaYeguas and J.M. Ibañez (2012). Evidence for magmatic underplating and partial melt beneath the Canary Islands derived using teleseismic receiver functions, Phys. Earth Plan. Int., 212, 44-54; doi:10. 1016/j.pepi.2012.09.004.

Longpré, M.A., A. Klügel, A. Diehl and J. Stix (2014). Mixing in mantle magma reservoirs prior to and during the 2011-2012 eruption at El Hierro, Canary Islands, Geology; doi:10.1130/G35165.1.

López, C., M.J. Blanco, R. Abella, B. Brenes, V.M. Cabrera Rodríguez, B. Casas, I. Domínguez Cerdeña, A. Felpeto, M. Fernández de Villalta, C. del Fresno, O. García, M.J. García-Arias, L. García-Cañada, L. Gomis Moreno, E. González-Alonso, J. Guzmán Pérez, I. Iribarren, R. López-Díaz, N. Luengo-Oroz, S. Meletlidis, M. Moreno, D. Moure, J. Pereda de Pablo, J. Rodero, E. Romero, S. Sainz-Maza, S.A. Sentre Domingo, P.A., Torres, P. Trigo and V. Villasante-Marcos (2012). Monitoring the volcanic unrest of El Hierro (Canary Islands) before the onset of the 2011-2012 submarine eruption, Geophys. Res. Lett., 39, L13303; doi:10.1029/2012GL051846. Martí, J., V. Pinel, C. López, A. Geyer, R. Abella, M. Tár- raga, M.J. Blanco, A. Castro and C. Rodríguez (2013a). Causes and mechanisms of the 2011-2012 El Hierro (Canary Islands) submarine eruption, J. Geophys. Res. Solid Earth, 118, 823-839; doi:10.1002/jgrb.50 087.

Martí, J., A. Castro, C. Rodríguez, F. Costa, S. Carrasquilla, R. Pedreira and X. Bolos (2013b). Correlation of Magma Evolution and Geophysical Monitoring during the 2011-2012 El Hierro (Canary Islands) Submarine Eruption, J. Pet., 54 (7), 1349-1373; doi:10.1093/petrology/egt014.

Meletlidis, S., A. Di Roberto, M. Pompilio, A. Bertagnini, I. Iribarren, A. Felpeto, P.A. Torres and C. D'Oriano (2012). Xenopumices from the 2011-2012 submarine eruption of El Hierro (Canary Islands, Spain): Constraints on the plumbing system and magma ascent, Geophys. Res. Lett., 39, L17302; doi:10.1029/2012GL052675.

Mogi, K. (1958). Relations between the eruptions of various volcanoes and the deformations of the ground surface around them, Bull. Earthquake Res. Inst., University of Tokyo, 36, 11-123.

Montesinos, F.G., J. Arnoso, M. Benavent and R. Vieira (2006). The crustal structure of El Hierro (Canary Islands) from 3-d gravity inversion, J. Volcanol. Geoth. Res., 150, 283-299; doi:10.1016/j.jvolgeores.2005.07.018.

Münn, S., and A. Klügel (2006). Gravitational spreading controls rift zones and flank instability on El Hierro, Canary Islands, Geol. Mag., 143, 257-268; doi:10.10 17/S0016756806002019.

Pérez, N.M., G.D. Padilla, E. Padrón, P.A. Hernández, G.V. Melián, J. Barrancos, S. Dionis, D. Nolasco, F. Rodríguez, D. Calvo and I. Hernández (2012). Precursory diffuse $\mathrm{CO}_{2}$ and $\mathrm{H}_{2} \mathrm{~S}$ emission signatures of the 2011-2012 El Hierro submarine eruption: Canary Islands, Geophys. Res. Lett., 39; doi:10.1029/20 12GL052410.

Pollard, D.D., O.H. Muller and D.R. Dockstader (1975). Form and growth of fingered sheet intrusions, Geol. Soc. Am. Bull., 86, 351-363; doi:10.1130/00167606(1975)86<351:TFAGOF>2.0.CO;2.

Prates, G., A. Garcia, A. Fernández-Ros, J.M. Marrero, R. Ortiz and M. Berrocoso (2012). Enhancement of sub-daily positioning solutions for surface deformation surveillance at El Hierro volcano (Canary Islands, Spain), B. Volcanol., 75, 724; doi:10.1007/s00 445-013-0724-3.

Ranero, C.R., M. Torne and E. Banda (1995). Gravity and multichannel the seismic reflection constraints on lithospheric structure of the Canary Swell, Mar. Geophys. Res., 17, 519-534; doi:10.1007/BF01204342. Rivera, J., G. Lastras, M. Canals, J. Acosta, B. Arrese, N. 
Hermida, A. Micallef, O. Tello and D. Amblas (2013). Construction of an oceanic island: Insights from the El Hierro (Canary Islands) 2011-2012 submarine volcanic eruption, Geology, 41 (3), 355-358; doi:10.11 30/G33863.1.

Roman, D.C., J. Neuberg and R.R. Luckett (2006). Assessing the likelihood of volcanic eruption through analysis of volcanotectonic earthquake fault-plane solutions, Earth Plan. Sci. Lett., 248, 244-252; doi:10. 1016/j.epsl.2006.05.029.

Rubin, A.M., D. Gillard and J.-L. Got (1998). A reinterpretation of seismicity associated with the 1983 dike intrusion at Kilauea Volcano, Hawaii, J. Geophys. Res., 103, 10003-10015; doi:10.1029/97JB03513.

Santana-Casiano, J.M., M. González-Dávila, E. FraileNuez, D. de Armas, A.G. González, I. Domínguez Cerdeña and J.F. Escánez (2013). The natural ocean acidification and fertilization event caused by the submarine eruption of El Hierro, Sci. Rep., 3; doi:10. 1038 / srep01140.

Schofield, N., C. Stevenson and T. Reston (2010). Magma fingers and host rock fluidization in the emplacement of sills, Geology, 38 (1), 63-66; doi:10.1130/ G30142.1.

Sigmarsson, O., D. Laporte, B. Devouard, J. Martí, J.L. Devidal and M. Carpentier (2012). Formation of Udepleted rhyolite from a basanite at El Hierro, Canary Islands, Contrib. Min. Pet., 165, 601-622; doi:10.1007/s00410-012-0826-5.

Smith, P.M., and P.D. Asimow (2005). Adiabat_1ph: A new public front-end to the MELTS, pMELTS, and pHMELTS models, Geochem. Geophys. Geosys., 6 (1); doi:10.1029/2004GC000816.

Stroncik, N.A., A. Klügel and T.H. Hansteen (2009). The magmatic plumbing system beneath El Hierro (Canary Islands): constraints from phenocrysts and naturally quenched basaltic glasses in submarine rocks, Contrib. Min. Pet., 157, 593-607; doi:10.1007/ s00410-008-0354-5.

Troll, V.R., A. Klügel, M.-A. Longpré, S. Burchardt, S., F.M. Deegan, J.C. Carracedo, S. Wiesmaier, U. Kueppers, B. Dahren, L.S. Blythe, T. Hansteen, C. Freda, D.A. Budd, E.M. Jolis, E. Jonsson, F. Meade, S. Berg, L. Mancini and M. Polacci (2011). Floating sandstones off El Hierro (Canary Islands, Spain): The peculiar case of the October 2011 eruption, Solid Earth Discussion, 3, 975-999; doi:10.5194/sed3-975-2011.

Villasante-Marcos, V., and F.J. Pavón-Carrasco (2014). Palaeomagnetic constraints on the age of Lomo Negro volcanic eruption (El Hierro, Canary Islands), Geophys. J. Int., 199, 1497-1514; doi:10.1093/gji/ ggu346.
Corresponding author: Alessio Di Roberto, Istituto Nazionale di Geofisica e Vulcanologia, Sezione di Pisa, Pisa, Italy; email: alessio.diroberto@ingv.it.

(C) 2015 by the Istituto Nazionale di Geofisica e Vulcanologia. All rights reserved. 